\title{
Akhisar ve Manisa Yörelerinin Yağıış ve Kuraklık İndisi Dizilerindeki Değişimlerin Hidroklimatolojik ve Zaman Dizisi Çözümlemesi ve Sonuçların Çölleşme Açısından Coğrafi Bireşimi
}

\author{
Hydroclimatological and time-series analysis of variations in precipitation and \\ aridity index series of the Akhisar and Manisa districts and geographical \\ synthesis of their consequences with respect to desertification
}

\author{
Murat Türkeș* \\ Çanakkale Onsekiz Mart Üniversitesi, Fen-Edebiyat Fakültesi, Coğrafya Bölümü, Çanakkale
}

\begin{abstract}
Öz: Bu çalışmada, yaklaşık son 30 yıllık dönemde Akhisar ve Manisa ovalarında gözlenen artan su sıkıntısının ve çölleşme süreçlerinin doğasını ve ulaştığı boyutu saptamak amacıyla, Akhisar ve Manisa yörelerinin iklimi ve hidroklimatolojik özellikleri ile iklim değişikliği ve değişkenliği ayrıntılı olarak çözümlendi. Çalışmada, Manisa Ovasını da içeren Aşağı ve Orta Gediz Ovaları ile Akhisar Ovasını temsil eden sırasıyla, Manisa, Salihli, Turgutlu ve Akhisar meteoroloji istasyonlarının uzun süreli verilerinden yararlanıld. Manisa ve Akhisar yörelerindeki uzun süreli iklimsel değişimler ve ĕgilimler, yıllık ve mevsimlik normalleştirilmiş yağış indisi (NYI) ve yıllık kuraklık indisi (KI) zaman dizileri kullanılarak çözümlendi. NYİ ve Kİ zaman dizilerinde gözlenen uzun süreli eğilimlerin doğasl ve büyüklüğü (istatistiksel anlamlılı̆̆l), parametrik olmayan Mann-Kendall sıra ilişki katsayısı $(\tau)$ ve parametrik en küçük kareler doğrusal regresyon yöntemleri ile incelendi. Yıllık NYİ ve Kİ zaman dizilerine uygulanan eğilim sinamalarl, Akhisar ve Manisa yörelerinde belirgin bir kuraklaşma eğiliminin yaşandı̆̆ını ve bu ĕgilimin 1980’lerle birlikte kuvvetlendiğini; 2007-2008 döneminde ise, kuraklık olaylarının şiddetlendiğini gösterir.
\end{abstract}

Anahtar kelimeler: İklim değişikliği, kuraklık ve çölleşme; Mann-Kendall sıra ilişki katsayısı: Doğrusal regresyon; Manisa ve Akhisar ovalarl; Akselendi Ovası.

\begin{abstract}
This study performed a detailed analysis of climate and hydro-climatologic characteristics along with climate change and variability of the Akhisar and Manisa districts in order to climatologically determine nature and degree of observed increasing water scarcity and desertification processes over the Akhisar and Manisa plains during the period of about last 30 years. In the study, the data of stations having the long-term climatic series of observations have been made use of. The stations chosen for the study consist of Manisa, Salihli, Turgutlu and Akhisar meteorology stations of the Turkish State Meteorological Service, representing the Lower and Upper Gediz, Manisa and Akhisar plains, respectively. Long-term climatic variations and trends over the Manisa and Akhisar districts were analyzed by using time-series of annual and seasonal normalized precipitation index (NPI) and annual aridity index (AI). Nature and magnitude (statistical significance) of the observed long-term trends in the NPI and AI time-series were investigated with the non-parametric MannKendal rank correlation coefficient $(\tau)$ and the parametric least-squares linear regression methods. Trend tests applied to the NPI and AI time-series indicate that the Akhisar and Manisa districts have faced an apparent drying trend, and this trend has become stronger since the 1980s along with the severe drought events during the period of 2007 to 2008 .
\end{abstract}

\footnotetext{
* İletişim: M. Türkeş, e-posta: comu.muratturkes@gmail.com
} 
Keywords: Climate change, drought and desertification; Mann-Kendall rank correlation coefficient; linear regression; Akhisar and Manisa plains; Akselendi Plain.

\section{Giriş, Kuram ve Çalışmanın Amacı}

\subsection{Su Kaynakları, İklim Değişikliği ve Kuraklık}

Fosil yakıtların yakılması, arazi kullanımı değişiklikleri, ormansızlaşma ve sanayi süreçleri gibi çeşitli insan etkinlikleri, sera gazlarının atmosferdeki birikimlerinin sanayi devriminden beri hızla artmasına neden olmuştur. Bu ise, Yerküre'nin enerji dengesini değiştirmekte (pozitif 1şınımsal zorlama) ve atmosferin yeryüzüne yakın katmanlarını 1sıtmaktadır. Bazı bölgelerde ise, çeşitli aerosoller, enerji dengesi üzerinde zıt bir etki (negatif ışınımsal zorlama) yaparak, atmosferi soğutma eğilimindedir (Türkeş 2008a, 2008b). Aerosollerin (havada asılı durabilen, uçucu küçük parçacık) atmosferdeki ömürleri kısa olduğu ve hava kirleticilerinin gelecekteki küresel salımlarında önemli düzeyde bir atış öngörülmediği için, aerosoller, atmosferik ömürleri uzun ve küresel 1sınma potansiyelleri yüksek olan sera gazlarının uzun süreli küresel etkilerini bastırabilecek güçte değildir. Sera gazlarının atmosferik birikimlerindeki bu artışların, sıcaklık, yağış, hava ve toprak nemi gibi iklim ve iklim-ilişkili değişkenlerinde bölgesel ve küresel değişikliklere yol açması beklenmektedir (Türkeş 2008a). Beklenen değişiklikler ise, giderek kendisini daha belirgin olarak göstermektedir. Örneğin, Küresel yüzey sıcaklıklarında 19. yüzyılın sonlarında başlayan 1sınma, 1980'li y1llardan sonra daha da belirginleşerek, küresel sıcaklık rekorları kırmıştır. Küresel iklimde gözlenen ısınmanın yanı sıra, Hükümetlerarası İklim Değișikliği Paneli’nin (IPCC) Dördüncü Değerlendirme Raporu’nda (IPCC, 2007) temel alınan en gelişmiş iklim modellerinin projeksiyonlarına (kestirimlerine) göre, atmosferdeki $\mathrm{CO}_{2}$ birikimlerinin iki katına çıkması sonucunda, 2100 yılına kadar küresel ortalama yüzey sıcaklıklarındaki artış, yaklaşı $3{ }^{\circ} \mathrm{C}^{\prime}$ lik en iyi kestirme değeriyle birlikte, büyük bir olasılıkla 2$4.5^{\circ} \mathrm{C}$ aralığında olacaktır. Ayrıca, IPCC'nin Emisyon Senaryoları Özel Raporu'nun (SRES) içerdiği birçok salım senaryosu (IPCC, 2000), gelecek 20 yıl için yaklaşık $0.2{ }^{\circ} \mathrm{C} / 10$ yıl oranında bir ısınmanın olacağını öngörmüştür. Öte yandan, tüm sera gazlarının ve aerosollerin birikimleri 2000 yılı düzeylerinde tutulsa bile, en azından yaklaşık $0.1{ }^{\circ} \mathrm{C} / 10$ yıl oranındaki bir isınmanın olacağ $\mathrm{da}$ beklenmektedir. Öngörülen 1sınma oranları, 20. yüzyılda gözlenen değişikliklerden daha büyüktür ve eski iklim verilerine dayanarak, yüksek bir olasılıkla bu oranın en azından son 10,000 yıl boyunca bir benzerinin gerçekleşmediği söylenebilir.

Küresel sıcaklıklardaki artışlara bağlı olarak da, hidrolojik döngünün değişmesi, kara ve deniz buzullarının erimesi, kar ve buz örtüsünün alansal daralması, deniz seviyesinin yükselmesi, iklim kușaklarının yer değiștirmesi, sıcak hava dalgalarının daha șiddetli ve sık olușması, bazı bölgelerde aşırı yăğşların ve taşkınların, bazı bölgelerde ise kuraklıkların daha şiddetli ve sık oluşması ile yüksek sıcaklıklara bağlı salgın hastalıkların ve zararlıların artması gibi, dünya ölçeğinde sosyoekonomik sektörleri, ekolojik sistemleri ve insan yaşamını doğrudan etkileyecek önemli değişikliklerin olması beklenmektedir.

Öngörülen iklim değişiklikleri, su kaynakları, tarım, doğal ekosistemler ve insan sağlığı üzerinde çoğunlukla olumsuz etkilere sahiptir. İklimdeki değişiklikler büyüdükçe, olumsuz etkilerin egemenliği de artacaktır. Sosyoekonomik sektörler (örn. tarım, ormancılık, balıkçılık, su kaynakları ve insan yerleşmeleri, vb.), kara ve su ekosistemleri ile insanoğlunun gelişimi ve refahı için çok yaşamsal olan insan sağlığı, iklimsel uç olaylardaki ve değişebilirlikteki değişikliklerde olduğu kadar, iklim değişikliğinin büyüklüğüne ve hızına karşı oldukça duyarlıdır.

İklim değişikliğinin, örneğin sıcaklıkta küçük artışlar olması durumunda, orta ve yüksek enlemlerde tarımsal üretimin artması ve kış ölümlerinin azalması gibi bazı olumlu sonuçları bulunmasına karșın, etkilerin çoğu, özellikle uç hava olaylarındaki bir artıș karșısında olumsuzdur ve pek çok doğal sistem ve çoğu insan bu değişikliklerden olumsuz olarak etkilenir. İklim modellerinin ürettiği kestirimler, iklim değişikliğinin etkileri açısından özetle aşağıda verilenleri içerir (Türkeş, 2008a, 2008b, 2010a): 
- $\quad$ Su açığının bulunduğu birçok alanda, özellikle tropikal ve subtropikal bölgelerde (Akdeniz havzasını ve Türkiye'yi de içerir), su varlı̆̆ında bir azalma;

- $\quad$ Sıcaklıktaki herhangi bir artış için, tropikal ve subtropikal bölgelerin (Akdeniz havzasını ve Türkiye'yi de içerir) çoğunda, tarımsal üretkenlikte bir azalma;

- Isı stresi ölümlerinden ve salgın hastalıklardan (örn. malarya, bulaşıcı humma, kolera, vb.) etkilenen insan sayısında bir artış;

- $\quad$ Artan kuvvetli yağış olayları ve deniz seviyesi yükselmesi nedeniyle, taşkın riskinde on milyonlarca insanı ilgilendiren yaygın bir artış;

- $\quad$ Özellikle buzullar, mercan resifleri ve atoller, mangrovlar, polar ve alpin ekosistemler gibi bazı doğal sistemlerde önemli ve çoğu kez geriye dönüşü olmayan ya da onarılmaz hasarlar;

- $\quad$ Bazı duyarlı türlerin yok olma ve biyolojik çeşitliliğin kaybolma tehlikesinde bir artış.

Etkileri açısından bu kadar çok farklı ve önemli değişiklik öngörüleri, uyum yeteneğinin iklim değişikliğinin etkilerini en aza indirme çabalarını sürdürme ve tamamlama açısından gerekli ve yaşamsal bir strateji olduğunu gösterir.

İklim değişikliğinin su kaynakları üzerindeki olası etkileri, bugünkü iklim koşulları altında yağışın yeryüzündeki eşitsiz dağılışı, kuraklık eğilimleri ve yoksulluk dikkate alındığında çok daha önemli olmaktadır. Çeşitli sera gazı salım senaryolarına dayalı iklim modeli kestirimleri, iklim değişikliğinin dünyanın kurak ve yarıkurak alanlarındaki su sıkıntısını kuvvetlendirebileceğini öngörmektedir. Bugünkü koşullarda, dünyada yaklaşık 1.5 milyar insan temiz su sağlayamıyor. 2 milyar insan da, yeterli ve sağlıklı yaşam koşullarından yoksun durumdadır. Günümüzde, çoğu Orta Doğu'da ve Afrika'da bulunan 19 ülke su kitlığı çeken ya da su stresi yaşayan ülke olarak sınıflandırılır. İklim değişikliği olmasa bile, bu sayının 2025'e kadar iki katın üzerinde bir artış göstereceği bekleniyor. Bunun temel nedeni, ekonomik büyümeden ve nüfus artışından kaynaklanan istemdeki artışlardır. Ne yazık ki, dünyanın pek çok bölgesinde suyun önemli bir bölümü, büyük ölçüde tarım sektöründeki verimsiz sulama yoluyla boşa harcanıyor. Akarsu akımlarının, yüksek enlemlerde ve Güneydoğu Asya'da artacağı, Orta Asya'da, Akdeniz havzasının çevresinde, güney Afrika ve Avustralya'da azalacağı öngörülüyor. Bu yüzden iklim değişikliği, kuraklığın zaten yinelenen bir doğal özellik olduğu bölgelerde, kuraklık olaylarının büyüklügünü ve sıklığını şiddetlendirirken, birçoğu kurak ve yarıkurak alanlarda bulunan gelişmekte olan ülkelerin iklim değişikliğine duyarlılıklarını daha yüksek düzeylere çıkaracaktır.

Konu tarımsal üretkenlik ve gıda güvenliği açısından da ele alınabilir. Bugünkü koşullar altında, yaklaşık 1 milyar insan yetersiz beslenmektedir. Temel olarak, dünya nüfusunun büyümesine ve bazı ülkelerde de gelirlerin artmasına bağlı olarak, gıda tüketiminin gelecek 30-40 yıllık dönemde ikiye katlanacağı bekleniyor. Konuyla ilgili çalışmalar, küresel tarımsal üretimin, iklimdeki küçük değişiklikler için (örn. küresel ortalama yüzey sıcaklığı değişikliklerinin yalnız birkaç ${ }^{\circ} \mathrm{C}$ olması durumunda), temel üretime göre sürdürülebileceğini göstermektedir. Ancak, iklim değişiklikleri nedeniyle toplam üründeki ve üretkenlikteki değişiklikler, bölgesel ve yöresel olarak önemli düzeyde değişecek ve buna bağlı olarak da üretim deseni değişebilecektir.

Genel olarak, ürün tipine, büyüme mevsimine, sıcaklık rejimindeki değişikliklere ve yağışın mevsimselliğine göre, sıcaklıktaki küçük değişiklikler dikkate alınarak orta ve yüksek enlemlerde üretkenliğin artacağı öngörülüyor. Buna karş1lık, 2-3 ${ }^{\circ} \mathrm{C}$ 'nin üzerindeki sıcaklık değişikliklerinde, orta enlemlerin tarımsal üretkenliğinde azalma olacağı bekleniyor. Ancak, tropikal ve subtropikal bölgelerde bazı ürünlerin kendi maksimum sıcaklık dayanıklılığına yakın olduğu yerlerde ve kurak arazilerin ve sulama yapılmayan tarımsal uygulamaların egemen olduğu yerlerde, tarımsal ürün tutarları sıcaklıktaki küçük artışlarda bile, özellikle Afrika'da, azalabilecektir. Ayrıca, tüm tarımsal üretkenliğin \% 30 dolayında azaldığı Afrika ve Latin Amerika'da üretkenlikteki azalmanın gelecek yüzyıl boyunca süreceği öngörülüyor. Bu yüzden, dünyanın yoksul halklarının çoğunun yaşadığı tropikal ve subtropikal bölgelerdeki bazı yerlerde, açlık tehlikesinde artış olabilecektir.

Türkiye'de ve onu çevreleyen bölgelerde (genel olarak Balkanları ve Orta Doğu Bölgesini içeren Doğu Akdeniz Havzası) gözlenen iklim değişikliği ve değişkenliğine ilişkin çalışmalar ile 
çeşitli sera gazı senaryolarına dayalı küresel ve bölgesel iklim modellerinin benzeştirmeleri ve kestirimleri, Türkiye'de önemli iklimsel değişimlerin olduğunu ve Akdeniz havzasındaki birçok ülke ile birlikte gelecekte Türkiye'nin de iklim değişikliğinden olumsuz etkileneceğini gösterir (örn. Demir vd. 2008; IPCC, 2001, 2007; Önol ve Semazzi, 2009; Tatli vd., 2004, 2005; Trigo vd., 2006; Türkeş, 1996, 1998, 1999, 2003a, 2003b, 2007, 2008a, 2008b, 2008c; Türkeş ve Acar, 2008; Türkeş ve Erlat, 2003, 2005; Türkeş ve Sümer, 2004; Türkeş ve Tatl1, 2008, 2009; Türkeş vd., 2002; Türkeş vd., 2009, vb.).

Tüm bu nedenlerle, iklim değişikliğinin etkilerini önlemek ya da en azından azaltabilmek için, Türkiye'nin gelecekteki ikliminin öngörülmesi yaşamsal bir önem taşır. Ancak, Türkiye'nin gelecek iklimini ve gelecekteki iklim değişikliklerini ortaya koymaya yönelik bölgesel iklim modeli çalışmaları henüz oldukça sınırlıdır. Bu sınırlı araştırmalara, Önol ve Semazzi (2009) ve Demir vd. (2008)'nin çalışmaları örnek olarak verilebilir. Demir vd. (2008), İngiltere Meteoroloji Kurumu'nun (Hadley Centre for Climate Prediction and Research's Regional Climate Model), PRECIS (Providing REgional Climates for Impacts Studies) modelini kullanarak, Türkiye ve bölgesi için ayrıntılı iklim benzeştirmeleri ve kestirimleri yapmıştır. Demir vd. (2008)'nin yararlandıkları iklim modeli, Hadley Centre'ın GCM HadAMP3 çıktılarını, 1961-1990 referans dönemini ve bununla karşılaştırmak içinse 2071-2100 gelecek dönemini kullanır. İklim değişikliği çözümlemelerinde HadAMP3 A2 senaryo benzeştirmeleri öteki sonuçlarla da karşılaştırılır.

Demir vd. (2008)'nin iklim modeli benzeştirmelerinin sonuçlarına göre, kıyı bölgeleri dışında Türkiye'nin büyük bölümünde yıllık ortalama hava sıcaklıkları gelecekte (2071-2100 döneminde) 5-6 ${ }^{\circ} \mathrm{C}$ kadar artabilecektir. Onlara göre, mevsimlik ortalama sıcaklıkların da tüm Türkiye'de artması beklenmektedir. Kış mevsiminde, Türkiye'deki genel bir artışla birlikte Doğu Anadolu Bölgesi’nde 4$6{ }^{\circ} \mathrm{C}^{\prime}$ ye ulaşabilecek bir artış beklenirken, yazın yine Türkiye ölçeğindeki genel bir atışla birlikte en yüksek sıcaklık artışı 6-7 ${ }^{\circ} \mathrm{C}$ ile ülkenin orta-batı bölgesinde beklenir. Öte yandan, Demir vd. (2008), kışın minimum hava sıcaklıklarının ülke ölçeğindeki genel bir artışla birlikte Doğu Anadolu Bölgesi'nde $5-6{ }^{\circ} \mathrm{C}$ kadar artacağını, yaz hava sıcaklıklarında ise ülke ölçeğindeki belirgin bir artışla birlikte Ege Bölgesi'nin iç bölümünde (İç Batı Anadolu) 7-8 ${ }^{\circ} \mathrm{C}^{\prime}$ ye ulaşan önemli bir 1sınmanın oluşacağını kestirmiştir (şekil verilmedi).

\section{2. Çalışma Alanının Genel Coğrafya Özellikleri}

Coğrafi olarak, Türkiye'nin batısında Ege Bölgesi'nin asıl Ege Bölümü Manisa ve Akhisar yörelerinde yer alan çalışma alanı, genel olarak, Salihli ilçesine göre Gediz çöküntüsünün (grabeninin) yakın çevresinde ve kuzeyinde, verimli tarım alanları özelliğini taşıyan Manisa Ovası'nı da içeren Aşağı ve Orta Gediz ovalarını ve Akhisar Ovası'nı içerir (Şekil 1). Daha ayrıntılı söylemek gerekirse, fiziki coğrafya özellikleri açısından çalışma alanı, Aşağı ve Orta Gediz ovalarından Alaşehir-Sarıgöl, Salihli, Turgutlu ve Manisa ovaları ile kuzeyde Akhisar Ovasını ve çok genel olarak güney sınırını oluşturan Bozdağlar (2159 m) ve Yamanlar-Manisa Dağı dağlık alanlarını, kuzeybatıda Yunt Dağı alçak dağ ve platolarını doğuda ise Gördes-Uşak Platosunu kapsar (Şekil 1). Aşağı Gediz ovalarının kabaca orta bölümünde, Manisa - Turgutlu - Gölmarmara üçgeninin ortasında ise Çal Dağı (1034 m) yer alır. Çalışma alanı ve yakın çevresi, doğal yüzey suyu kaynakları açısından, güneyinden akan Gediz Nehri ve doğusundaki Marmara Gölü dışında zengin değildir. Bunların dışında, yörenin yaklaşık kuzeydoğusunda ve yine yöreye yakın önemli bir yüzey suyu kaynağı, Demirköprü Baraj gölüdür (Şekil 1). 


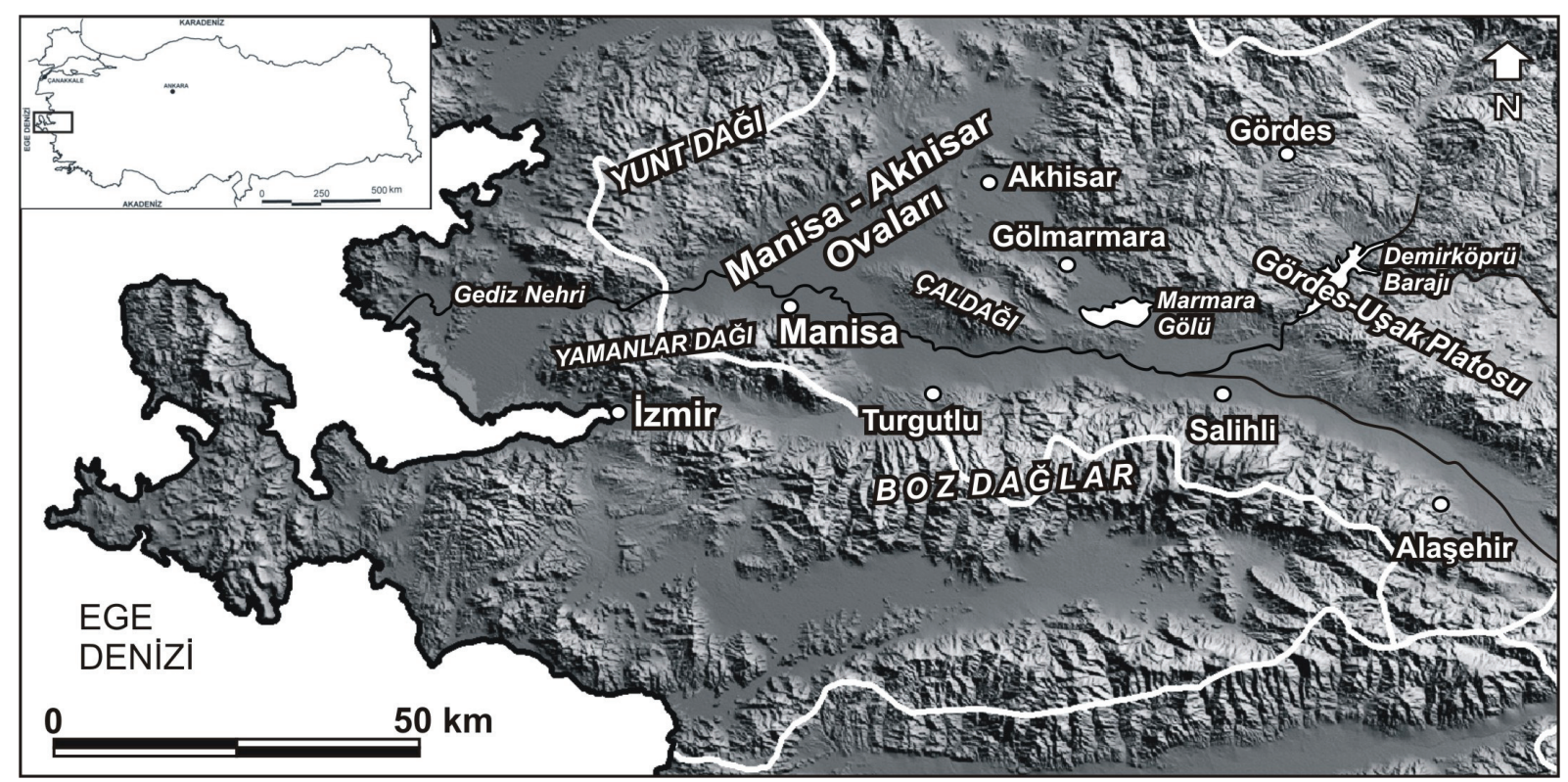

Şekil 1. Ege Bölgesi - Ege Bölümü Akhisar ve Manisa yörelerinin (Akhisar-Manisa ve Aşağı ve Orta Gediz ovaları) sadeleştirilmiş fiziki ve yerbulduru haritası.

Manisa ve Akhisar ovalarının klimatolojisine ilişkin olarak yapılmış başlıca iki çalışma vardır. Bunlardan birincisi, Temuçin (1991)'in, Manisa ve Akhisar ovalarında iklim ve ortam ilişkilerinin ele alındığı doktora çalışmasıdır. İkincisi ise, Koçman'ın (1993), Ege ovalarının genel fiziki coğrafya özelliklerinin de dikkate alındığı bir araştırma kitabı çalışmasıdır. Koçman (1993) Ege ovalarındaki egemen iklim koşullarının insan yaşamı ve çeşitli çevresel öğeler üzerindeki etkilerini araştırdığı bu kapsamlı çalışmasında, Ege ovalarının klimatolojik özelliklerini ayrıntılı bir biçimde incelemiştir.

Genel olarak $580 \mathrm{~mm}$ ve $720 \mathrm{~mm}$ arasında değişen orta düzeyde bir yıllık ortalama toplam yağış alan Manisa ve Akhisar yörelerinde (Çizelge 1), özellikle kuzeye ve batıya bakan yüksek dağ yamaçlarında farklı yağış rejim çeşitleri (örn. daha yükssek y1llık yağış ve daha türdeş bir mevsimlik dağılış) ve ortalama toplam yağış tutarları gözlenebilecek olmasına karşın, yöre temel olarak gerçek Akdeniz yağış rejimine girer.

Çalışma alanı, geleneksel iklim sınıflandırmalarına göre, yarı nemli Akdeniz ya da daha ayrıntılı olarak "yazları sıcak ve kurak, kışları ılık ve yağışlı kurak-yarınemli ve yarınemli" olarak belirlenebilir. Çalışma alanı, iklim ve iklimsel değişkenlik açısından ise, "orta düzeyde bir yıllık yağış, yüksek mevsimlerarası ve yıllararası değişkenlik, çok sıcak ve kurak bir yaz ve yağışl ve ılıman bir kış mevsimi" (Çizelge 1) (Türkeş, 1996, 1998, 1999) ile "Türkiye geneline göre yüksek kabul edilebilecek kuraklık olasıllı̆g" ile nitelenir (Türkeş ve Tatl1, 2008, 2009). Hidroklimatolojik açıdan, yörenin en belirgin özelliği ise, "kuvvetli bir yıllık su açığının bulunması ve yılın 6 aylık sıcak ve kurak döneminde toprak nem dengesinin kuraklık yönünde çok fazla bozulması ve su açı̆̆ının kuvvetlenmesidir."

\section{3. Çalışmanın Amacı}

Bu yüzden çalışmanın amacı, yaklaşık son 30 yıllık dönemde Akhisar, Aşağ1 ve Orta Gediz ovalarında gözlenen artan su sıkıntısının ve çölleşme süreçlerinin ulaştığı boyutu klimatolojik olarak saptamak için, Akhisar ve Manisa yörelerinin iklimi ve hidroklimatolojik özellikleri ile iklim değişikliği ve değişkenliğini ayrıntılı bir biçimde çözümlemek olarak belirlendi. 
Çizelge 1. Uzun süreli klimatolojik verileri bulunan Akhisar (1929-2008), Manisa (1929-2008) ve Salihli (1939-2008) meteoroloji istasyonlarının, mevsimlik ve yıllık yağış toplamlarının $(\mathrm{mm})$ uzun süreli ortalama (Ort.), standart sapma (StS), değişim katsayısı $(D K, \%)$ ve uzun süreli ortalamanın \% 95 olasılık düzeyindeki güven düzeyi $(G D)$, mevsimlik ortalama yağışın yıllık ortalama yağış tutarı içindeki payı $(M Y P, \%)$, uzun süreli yağış dizilerindeki en yükssek (Mak.) ve en düşük (Min.) mevsimlik ve yıllık yağış toplamları.

\begin{tabular}{|c|c|c|c|c|c|}
\hline \multirow{2}{*}{$\begin{array}{l}\text { Tanımsal } \\
\text { istatistikler }\end{array}$} & \multicolumn{5}{|c|}{ AKHİSAR } \\
\hline & $K \iota s ̧$ & İkbahar & $Y a z$ & Sonbahar & Ylllık \\
\hline Ort. (mm) & 281.6 & 148.0 & 22.5 & 128.5 & 580.4 \\
\hline$S t S(\mathrm{~mm})$ & 107.0 & 56.6 & 22.7 & 62.8 & 135.1 \\
\hline$D K(\%)$ & 38.0 & 38.3 & 101.3 & 48.9 & 23.3 \\
\hline$G D(\mathrm{~mm})$ & 23.6 & 12.5 & 5.0 & 13.8 & 29.8 \\
\hline$M Y P(\%)$ & 48.5 & 25.5 & 3.9 & 22.1 & \\
\hline Mak. (mm) & 542.4 & 326.0 & 125.8 & 337.0 & 902.4 \\
\hline \multirow[t]{2}{*}{ Min. (mm) } & 82.2 & 40.6 & 0.0 & 20.3 & 311.2 \\
\hline & \multicolumn{5}{|c|}{ MANISA } \\
\hline Ort. (mm) & 365.0 & 173.6 & 24.6 & 155.6 & 718.9 \\
\hline$S t S(\mathrm{~mm})$ & 131.6 & 62.1 & 21.0 & 69.2 & 166.0 \\
\hline$D K(\%)$ & 36.1 & 35.8 & 85.3 & 44.5 & 23.1 \\
\hline$G D(\mathrm{~mm})$ & 29.0 & 13.7 & 4.6 & 15.3 & 36.6 \\
\hline$M Y P(\%)$ & 50.8 & 24.1 & 3.4 & 21.6 & \\
\hline Mak. (mm) & 657.3 & 343.9 & 83.6 & 349.3 & 1165.5 \\
\hline \multirow[t]{2}{*}{ Min. (mm) } & 85.6 & 59.1 & 0.0 & 29.1 & 406.2 \\
\hline & \multicolumn{5}{|c|}{ SALİHLİ } \\
\hline Ort. (mm) & 221.3 & 133.9 & 26.2 & 105.9 & 485.8 \\
\hline$S t S(\mathrm{~mm})$ & 78.2 & 49.9 & 22.5 & 53.8 & 99.8 \\
\hline$D K(\%)$ & 35.3 & 37.2 & 85.7 & 50.8 & 20.6 \\
\hline$G D(\mathrm{~mm})$ & 18.4 & 11.8 & 5.3 & 12.7 & 23.6 \\
\hline$M Y P(\%)$ & 45.6 & 27.6 & 5.4 & 21.8 & \\
\hline Mak. (mm) & 423.6 & 310.8 & 118.1 & 289.3 & 750.1 \\
\hline Min. (mm) & 69.2 & 34.3 & 0.8 & 13.3 & 294.2 \\
\hline
\end{tabular}

\section{Veri ve Çözümleme Yöntemleri}

\subsection{Veri}

Çalışmada, Devlet Meteoroloji İşleri Genel Müdürlüğü’nün (DMI), Akhisar, Manisa, Aşağı ve Orta Gediz ovalarını temsil eden, Akhisar, Manisa, Salihli ve Turgutlu klimatoloji/meteoroloji istasyonlarının uzun süreli verilerinden yararlanıldı. Çizelge 2, çalışmada kullanılan istasyonlara ilişkin bilgileri gösterir. Bu istasyonlardan yağış zaman dizileri uzun olan Akhisar (1929-2008), Manisa (1929-2008) ve Salihli (1939-2008) meteoroloji istasyonlarının tanımsal yağış istatistikleri hesapland1 ve Çizelge 1'de verildi.

Manisa, Akhisar, Salihli ve Turgutlu meteoroloji istasyonlarının uzun süreli aylık toplam yağış ve aylık ortalama sicaklık zaman dizilerinden yararlanılarak, Thornthwaite (Thornthwaite, 1948) iklim sınıflandırması ve Thornthwaite su bilançoları hesaplandı (bkz. Çizelge 3, Şekil 2). 
Çizelge 2. Çalışma için seçilen istasyonlar ve bazı tanıtıcı özellikleri.

\begin{tabular}{|c|c|c|c|c|}
\hline Ístasyon & $\begin{array}{l}\text { Istasyon } \\
\text { Numarast }\end{array}$ & Enlem & Boylam & $\begin{array}{l}\text { Ístasyon } \\
\text { Yük. (m) }\end{array}$ \\
\hline Manisa & 17186 & $38^{\circ} 37^{\prime}$ & $27^{\circ} 26^{\prime}$ & 113 \\
\hline Akhisar & 17184 & $38^{\circ} 55^{\prime}$ & $27^{\circ} 51^{\prime}$ & 135 \\
\hline Salihli & 17792 & $38^{\circ} 29^{\prime}$ & $28^{\circ} 08^{\prime}$ & 143 \\
\hline Turgutlu & 05615 & $38^{\circ} 30^{\prime}$ & $27^{\circ} 42^{\prime}$ & 120 \\
\hline
\end{tabular}

\subsection{Yöntem}

\subsubsection{Normalleş̧irilmiş yağış indisi}

Manisa ve Akhisar yörelerindeki yağış ve kuraklık koşullarındaki uzun süreli değişimler ve eğilimler, normalleştirilmiş yıllık yağıș ve yıllık kuraklık indisleri kullanılarak incelendi. Normalleştirilmiş yağış indisi (NYI) (Türkeş, 1996, 1998; Türkeş ve Tatlı, 2010; vb.), y1llık yağgş dizilerindeki yıllık toplamların, bu dizilerin uzun süreli ortalama ve standart sapması kullanılarak standartlaştırılması yoluyla elde edilir.

\subsubsection{Kuraklık indisi}

Kuraklık indisi $(K \dot{I})$, Thornthwaite su bilançosunda kullanılan toplam yağış ve su bilançosu için hesaplanan toplam düzeltilmiş potansiyel evapotranspirasyon $(D P E)$ değerleri kullanılarak hesaplanır (Türkeş, 1999). Bu çalışmada yapıldığ 1 gibi kuraklık (ya da kurak iklimleri ve arazileri belirleme) indisinin zaman dizisi hesaplanacaksa, bu durumda hesaplamada her yılın (ya da donsuz ay ve mevsimlerin) toplam yağışı $(Y)$ ve o yıl (ya da donsuz ay ve mevsim) için hesaplanan $D P E$ değerleri kullanılır $(K \dot{I}=Y / D P E)$ (Türkeş, 1999; Türkeş ve Tatlı, 2010; vb.).

\subsection{3. Ĕgilim sinamaları}

Normalleştirilmiş yıllık ve mevsimlik (burada verilmedi) yağış ve yıllık kuraklık indisi zaman dizilerinde gözlenen uzun süreli eğilimlerin doğası (yönü) ve büyüklüğü (istatistiksel anlamlılı̆̆1), parametrik olmayan Mann-Kendall sıra ilişki katsayısı ( $\tau$ ) (WMO, 1966; Türkeş vd., 2009) ve en küçük kareler doğrusal regresyon (EKKDR) (Wonnacott ve Wonnacott, 1972; Türkeş, 2009a, 2009b) yöntemleri ile incelendi. Mann-Kendall $(M-K)$ sıra ilişki katsayısı $(\tau)$ 'nın anlamlılığ normal dağılımın, EKKDR katsayısı $\beta$ nın anlamlılığ için Student $t$ sınaması Student $t$ dağılımının iki yanlı şekline göre 0.05 ve 0.01 anlaml1lık düzeylerinde sinandı (bkz. Çizelge 5).

\section{(1) Mann-Kendall sıra ilişki katsayısı}

$M-K$ sıra ilişki katsayısı tau'nun $(\tau)$ hesaplanmasında, çözümlemesi yapılan $x_{i}$ elemanlı orijinal gözlem dizisinin yerine, onların küçükten büyüğe dizilmesiyle elde edilen sıra numaralarından oluşan $k_{i}$ dizileri temel alınır. Başka bir deyişle, önce her terimin kaçıncı sırada yer aldığı bulunur ve sıralı dizi $k_{i}$ elde edilir. İkinci olarak $P$ istatistiği hesaplanır. Oluşturulan $k_{i}$ dizilerindeki ilk terimin değeri ikinci terimin değerinden $N^{\prime}$ inci terime kadar, dizideki tüm terimlerin değerleriyle karşıllaştırılır. $k_{l}{ }^{\prime} i$ aşan terimlerin sayısı bulunur ve $n_{l}$ olarak gösterilir. Aynı işlem ikinci terimin değeri ile ondan sonraki terimler arasında gerçekleştirilir ve $k_{2}$ 'yi aşan sonraki terimlerin sayısı $n_{2}$ olarak gösterilir. Bu işlem $k_{n-}$ $l^{\prime}$ 'e kadar, dizideki her terim için gerçekleştirilir. $n_{i}{ }^{\prime}$ lerin toplamı, Denk. (1)'de gösterilen $P$ istatistiğini verir.

$$
P=\sum_{i=1}^{N-1} n_{i}
$$


Olağan $M-K$ sınama örneklemdeğeri ( $\tau$ ), $N$ ve $P$ 'den yararlanılarak Denk. (2) ile hesaplanır:

$\tau=\frac{4 P}{N(N-1)}-1$

Tau ( $\tau)^{\prime}$ nun anlamlılık sinaması $(\tau)_{t}$, Denk. (3) ile hesaplanır:

$(\tau)_{t}=0 \mp t_{g} \cdot \sqrt{\frac{4 N+10}{9 N \cdot(N-1)}}$

Denk. (3)'deki $t_{g}$ normal dağılımın iki yanlı şekline göre, istenen anlamlılık düzeyine karşılık gelen kritik değerdir. Genel olarak, uygulamalarda $t_{g}$ için $\% 5$ ve $\% 1$ anlamlılık düzeylerine karşıllk gelen, sırasıyla 1.960 ve 2.576 kritik değerleri kullanılır. Ho (gözlemler herhangi bir eğilim içermiyor boş hipotezi), normal dağılımın iki yanlı şekline göre $(\tau)_{t}$ ile karşılaştırılan $\tau$ istatistiğinin büyük değerleri için reddedilir.

(2) EKKDR Çözümlemesi ve ß'nın anlamlılığı için Student t sinaması

$E K K D R$ katsayısı $\beta$ nın anlamlılığı için Student $t$ sınaması aşağıdaki gibi hesaplanır:

(a) En küçük kareler hesaplamaları için gerekli olan temel eşitlikler:

$i=1, \ldots, n$ 'e kadar, $X_{i}$ ve $Y_{i}$, iki değişkene ait diziler olmak üzere, $X$ ve $Y$ dizilerinin ortalamalar1:

$\bar{X}=\frac{\sum_{i=1}^{n} X_{i}}{n}$

$\bar{Y}=\frac{\sum_{i=1}^{n} Y_{i}}{n}$

En küçük kareler doğrusal regresyon denklemindeki $a$ katsayısı:

$a=\bar{Y}$

En küçük kareler doğrusal regresyon denklemindeki $b$ katsayısı:

$x_{i}=X_{i}-\bar{X}$ olmak üzere,

$b=\frac{\sum_{i=1}^{n} x_{i} \cdot Y_{i}}{\sum_{i=1}^{n} x_{i}^{2}}$

En küçük kareler doğrusal regresyon genel (9) ve tahmin (10) denklemleri:

$Y=a+b x$

$\hat{Y}_{i}=a+b \cdot x_{i}$

(b) $\hat{\beta}$ 'nın (regresyon ya da $X$ katsayısının) anlamlılığı için hipotez sınaması (Student $t$ sinamas1): 
Önce, $Y^{\prime}$ nin varyansı, $s^{2}$, aşağıdaki eşitlikle kestirilir:

$s^{2}=\frac{1}{n-2} \cdot \sum_{i=1}^{n}\left(Y_{i}-\hat{Y}_{i}\right)^{2}$

Burada, $\hat{Y}_{i}, \hat{Y}_{i}=\alpha+\hat{\beta} x_{i}$ tahmin eşitliği ile kestirilen regresyon çizgisi üzerindeki $Y$ 'nin kesaplanan (uydurulan) değeridir. $s^{2}$ ye, 'residual varyans' da denir; $s$ ise, $Y$ 'nin standart hatası olarak adlandırılır.

Sonra, $\beta$ nın (eğimin) anlamlılığı için Student $t$ sınaması gerçekleştirilir:

$t=\frac{\hat{\beta}-\beta}{\sqrt{s^{2} / \sum_{i=1}^{n} x_{i}^{2}}}$

$t$, (n-2) bağımsızlık sayısıyla birlikte Student $t$ dağılır. Yukarıdaki eşitlik (12) yalınlaştırılarak aşağıdaki gibi yeniden yazılabilir:

$t=\frac{\hat{\beta}-\beta}{S_{\hat{\beta}}}$

Denk. (13)'deki $S_{\hat{\beta}}, \hat{\beta}$ 'nın standart hatası ya da tahmini standart sapma olarak adlandırılır ve Denk (14) ile açıklanır:

$$
S_{\hat{\beta}}=\frac{s}{\sqrt{\sum_{i=1}^{n} x_{i}^{2}}}
$$

Sınama örneklemdeğeri $t,(n-2)$ bağımsızlık sayısıyla birlikte Student $t$ dağglır. "Gözlemlerde herhangi bir eğilim yoktur” boş hipotezi, dağılımın iki yanlı şekline göre $|t|$ 'nin büyük değerleri $\left(|t| \geq t_{\alpha / 2}\right)$ için reddedilir.

\section{3. Çözümleme Sonuçları ve Bireşimi}

\section{1. İklim ve Hidroklimatoloji}

Gediz çöküntüsünü ve onunla bağlantılı ovaların önemli bir bölümünü de içeren Akhisar ve Manisa yörelerinde, genel olarak Türkiye'nin batı ve güney bölgelerinde görülen, subtropikal karaların batı bölümlerinde oluşan, yazları sıcak ve kurak, kışları 1lık ve yağıșlı Akdeniz 'büyük' iklimi egemendir. Erinç yağış etkinliği ve Birleşmiş Milletler Çölleşmeyle Savaşım Sözleşmesi kuraklık indisi $(K \dot{I})$ gibi çeşitli iklim sınıflandırmalarına göre, çalışma alanının Manisa'nın Sipil Dağı dağlık yöresi ve Bozdağlar dağlık alanları dışında kalan geniş bir bölümünde, çölleşmeye eğilimli (çölleşme süreçlerine açık) kuru-yarınemli ve yarınemli iklim koşulları egemendir (Türkeş, 1990, 1999, 2010b). Doğrudan yağış gözlemleri bulunmamasına karşın, yağışın özellikle egemen hava akımlarına ve orta enlem siklonlarına karşı uygun bir bakıya sahip olan batı ve kuzey yamaçlarının onu çevreleyen ovalara göre görece daha yüksek bir yıllık toplam yağışa sahip olma olasılı̆̆ 1 vardır.

Çalışma alanı ve çevresi geleneksel iklim sınıflandırmalarına göre, gerçek Akdeniz iklimine ya da Akdeniz ikliminin Ege Bölümü’ne sokulurken, Türkeş'in $(1996,1998)$ Türkiye için geliştirdiği yağış rejimi sınıflandırmasına göre, en yüksek yağışın kışın, en düşük yağışın yazın kaydedildiği Akdeniz yağış rejimi özelliği gösterir (Çizelge 1, Şekil 2). Örneğin, çalışmada kullanılan 
istasyonlardan Manisa ve Turgutlu'nun Akdeniz yağış rejimi için tanıtıcı olan aylık yağış dağılışına göre, yılın en nemli ayı, sırasıyla $140.9 \mathrm{~mm}$ ve $84.8 \mathrm{~mm}$ uzun süreli ortalama yağış tutarları ile Aralık, en kurak ayı ise $4.3 \mathrm{~mm}$ ve $5.3 \mathrm{~mm}$ ile Ağustos'tur.

Belirgin mevsimselliğin yanı sıra, Akhisar ve Manisa yörelerindeki aylık (burada verilmedi) ve mevsimlik (Çizelge 1) toplam yağış dizilerindeki yıllararası değişenlik de çok yüksektir. Değişim katsayısı (DK) oranlarına göre, Haziran-Eylül döneminde yıllararası değişkenlik, \% 100’ün çok üzerindedir; oran Temmuz ve Ağustos'ta çok daha yüksek bir değişkenlik değerine ulaşır. Yaz mevsimindeki DK oranları da yüksektir ve \% 85 - \% 100 arasında değişir (Çizelge 1).

Çizelge 3. Thornthwaite iklim sınıflandırmasına göre Akhisar ve Manisa yörelerinin ayrıntılı iklim çeşitleri.

\begin{tabular}{|c|c|c|c|c|c|}
\hline Istasyon & $\begin{array}{c}\text { Nemlilik } \\
\text { indisi }\left(L_{\mathrm{m}}\right)\end{array}$ & $\begin{array}{l}\text { Sicaklık } \\
\text { etkinliği }\end{array}$ & $\begin{array}{c}\text { Yağlş rejimi indisi } \\
\left(I_{a}\right)\end{array}$ & $\begin{array}{c}\text { Yaz konsantrasyonu } \\
(\%)\end{array}$ & 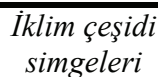 \\
\hline Manisa & 2.3 & 91.8 & 59.9 & 54.9 & $\mathrm{C}_{2} \mathrm{~B}^{\prime}{ }_{3} \mathrm{~s}_{2} \mathrm{~b}_{3}$ \\
\hline Akhisar & -8.8 & 87.6 & 27.7 & 54.3 & $\mathrm{C}_{1} \mathrm{~B}^{\prime}{ }_{3} \mathrm{~s}_{2} \mathrm{~b}_{3}{ }_{3}$ \\
\hline Salihli & -20.5 & 89.5 & 16.7 & 54.6 & $\mathrm{D} \mathrm{B}_{3} \mathrm{~d} \mathrm{~b}_{3}$ \\
\hline Turgutlu & -18.1 & 91.2 & 19.7 & 54.3 & $\mathrm{C}_{1} \mathrm{~B}_{3}{ }_{3} \mathrm{~s} \mathrm{~b}_{3}$ \\
\hline
\end{tabular}

Thornthwaite iklim sınıflandırmasına göre, çalışma alanını çevreleyen istasyonlarda, genel olarak, "kuru-yarınemli ve yarınemli, yll boyunca oldukça sıcak, yazın yüksek (şiddetli) su açı̆̆ının yaşandığı ve kışın belirli bir düzeyde su fazlasının ortaya çıktı̆̆ hafif karasal ya da denizel iklime yakın bir iklim" egemendir (Çizelge 3). Aşağıda yapılacak olan özetten ve yağışın yıl içindeki ve alansal dağılış özelliklerinden de anlaşılabileceği gibi (burada verilmedi), Manisa ve Akhisar yöreleri genel olarak, doğuya ve daha alçaktaki ovaların en alçak orta bölümlerine doğru gidildiğinde daha kurak niteliktedir. Çizelge 3'e göre, çalışmada kullanılan meteoroloji istasyonlarının ayrıntılı iklim özellikleri şöyle özetlenebilir:

Manisa: Yarınemli, oldukça sıcak, yazın şiddetli su açığının (toprak nem açığının) görüldüğü hafif karasal bir iklim.

Akhisar: Kurak-yarınemli, oldukça sıcak, kışın su fazlası çok olan hafif karasal bir iklim.

Salihli: Yarıkurak, oldukça sıcak, su fazlasının çok az olduğu hafif karasal bir iklim.

Turgutlu: Kurak-yarınemli, oldukça sıcak, kış mevsiminde orta düzeyde su fazlasının görüldüğü hafif karasal bir iklim.

Çalışma kapsamında, Manisa, Akhisar, Salihli ve Turgutlu istasyonları için yapılan Thornthwaite su bilançosu çözümlemesinin sonuçlarından yararlanarak, çalışma alanını temsil ettiğini kabul ettiğimiz bu dört istasyon için su bilançosu diyagramları da hazırlandı (Şekil 2). Thornthwaite su bilançosu diyagramları incelendiğinde, çalışma alanı ve çevresinin iklim koşullarının (özellikle yağış, sıcaklık, evapotranspirasyon rejimleri) oldukça türdeş olduğu, kışın toprakta su fazlasının (toprakta su ya da nem birikimi yeterli), yaz mevsiminde ise toprakta kuvvetli su açı̆̆ının (toprakta nem eksilmesi) bulunduğu görülür (Şekil 2a, b, c ve d). Daha ayrıntılı olarak şunlar söylenebilir: Çalışma alanı ve çevresinde,

- Mayıs-Haziran aylarında toprakta biraz kullanılabilir su bulunmasına karşın, genel olarak Mayıs-Ekim arasındaki 6 aylık dönemde toprakta su eksikliği (su açığı) olduğu; daha açık bir söyleyişle Mayıs-Ekim döneminin, yağışın potansiyel evapotranspirasyonu karşılamadığı, toprağın kuruduğu bir dönem olduğu,

- Olağan yaz devresine karşılık gelen Haziran, Temmuz ve Ağustos aylarında, topraktaki nem eksikliğinin en şiddetli düzeyine ulaştı̆̆ 1 ,

- Temmuz ve Ağustos aylarında, topraktaki su açı̆̆ının 150 mm'nin üzerine çıktığı,

- Yılın Aralık-Mart arasındaki 4 aylık yağışlı döneminde toprakta su fazlası olduğu;

- Nisan ayının nemli koşullardan kurak koşullara geçişi temsil ettiği,

- Kasım ayında ise, önce orta enlem, sonra Akdeniz alçak basınçlarıyla bağlantılı cephesel yağışların başlamasıyla birlikte toprakta suyun biriktiği ve nemliliğin arttığı görülür. 

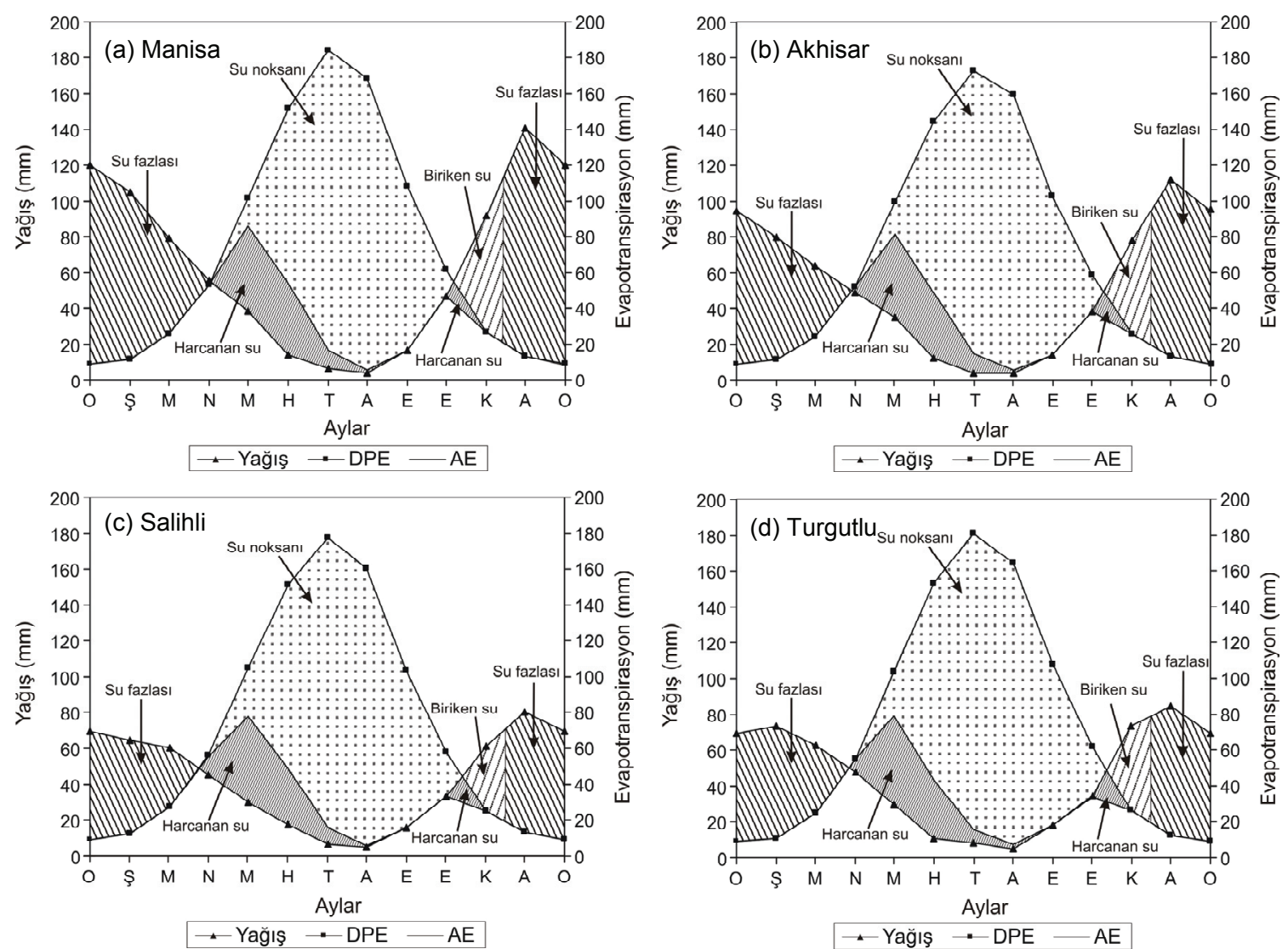

Şekil 2. Manisa (a), Akhisar (b), Salihli (c) ve Turgutlu (d) meteoroloji istasyonlarının Thornthwaite su bilançosu diyagramları. Burada, aylık ortalama yağış tutarının ( $\mathrm{mm}$ ) yanı sıra, $D P E$, düzeltilmiş potansiyel evapotranspirasyonu (mm) ve $A E$, gerçek evapotranspirasyonu (mm) gösterir.

Bunların dışında, Thornthwaite su bilançosu çizelgelerine göre (burada verilmedi) aşağıdaki bireşim de yapılabilir:

(1) Manisa'da yıllık ortalama toplam yağı̧s tutarı $719 \mathrm{~mm}$, hesaplanan yıllık toplam AE 368 mm, yılın Mayıs-Ekim arasındaki 6 aylık kurak devresindeki toplam su açığı 550 mm, Aralık-Mart arasındaki 4 aylık yağışlı devresindeki toplam su fazlası $351 \mathrm{~mm}$ ve yıllık toplam DPE tutarı 918 mm'dir.

(2) Akhisar'da yıllık ortalama toplam yağış tutarı $585 \mathrm{~mm}$, hesaplanan yıllık toplam AE tutarı $342 \mathrm{~mm}$, yılın Mayıs-Ekim arasındaki 6 aylık kurak devresindeki toplam su açığ $534 \mathrm{~mm}$, AralıkMart arasındaki 4 aylık yağışlı devresindeki toplam su fazlası $243 \mathrm{~mm}$ ve yıllık toplam düzeltilmiş potansiyel evapotranspirasyon tutarı $876 \mathrm{~mm}$ 'dir.

(3) Salihli'de yıllık ortalama toplam yağış tutarı $489.4 \mathrm{~mm}$, hesaplanan yıllık toplam AE tutarı $339 \mathrm{~mm}$, Mayıs-Ekim arasındaki 6 aylık kurak devrenin toplam su açığ $556 \mathrm{~mm}$, 4 aylık yağışlı devredeki toplam su fazlası $150 \mathrm{~mm}$ ve yıllık toplam düzeltilmiş potansiyel evapotranspirasyon tutarı 895 mm'dir.

(4) Turgutlu'da, yıllık ortalama toplam yağış tutarı $516 \mathrm{~mm}$, hesaplanan yıllık toplam AE tutarı $336 \mathrm{~mm}$, Mayıs-Ekim arasındaki 6 aylık kurak devrenin toplam su açığı $575 \mathrm{~mm}$, 4 aylık yağışlı devredeki toplam su fazlas $180 \mathrm{~mm}$ ve yıllık toplam düzeltilmiş potansiyel evapotranspirasyon tutarı 912 mm'dir. 
Çizelge 4. Türkiye'deki kurak ve nemli arazilerin sınıflandırılması ve çölleşme açısından değerlendirilmesi (Türkeş, 1999).

\begin{tabular}{lcl}
\hline Sinıflandırma & $K \dot{I}$ & Çölleşme açısından değerlendirme \\
\hline Çok kurak* & $<0.05$ & Gerçek iklimsel çöller (Türkiye'de yok) \\
Kurak & $0.05-0.19$ & Çölleşmeye açık (Türkiye'de yok) \\
Yarıkurak & $0.20-0.49$ & Çölleşmeye açık (Konya Ovası ve Iğdır yöresi) \\
Kuru-yarınemli & $0.50-0.64$ & Çölleşmeye açık (Güneydoğu ve iç bölgeler) \\
Yarınemli & $0.65-0.79$ & Çölleşmeye açık (Batıda ve kuru-yarınemlinin çevresinde) \\
Yarınemli & $0.80-0.99$ & Çölleşmeye eğilimli olabilir \\
Nemli & $1.00-1.99$ & Çölleşme yok (Temel olarak Karadeniz Bölgesi’nde) \\
Çok nemli & $2.00<$ & Çölleşme yok (Rize ve Hopa yöresinde) \\
\hline
\end{tabular}

(*) İtalik ile belirtilen kuraklık sınıfları, çölleşmeye açık ‘kurak arazileri’ gösterir.

\subsection{Yağış ve Kuraklık İndisi Dizilerindeki Değişimler ve Eğilimler}

Manisa yöresindeki uzun dönemli yağış-nemlilik ya da kuraklık koşullarında herhangi bir değişiklik olup olmadığı ve yağış-kuraklık indisi dizilerindeki kısa ve uzun süreli değişkenlikleri görsel olarak gösterebilmek ve değerlendirebilmek için, Manisa, Akhisar ve Salihli meteoroloji istasyonlarının zaman dizisi grafikleri çizildi.

Hazırlanan zaman dizisi çizimlerinin (a) ile gösterilen kuraklık indislerinin yıllararası değişim grafiklerinde (Şekil 3a, 4a, 5a), kuraklık indisinin iklim ya da kuraklık indisi olarak kullanıldığında temel alınan ve Çizelge 4'te verilen kuraklık sınıfları, indis değerinin büyüklügüne göre uygun yerde gösterilmiştir. Ayrıca, kuraklık-nemlilik koşullarının değişiminin nesnel bir karşılaştırmasını yapabilmek amacıyla, bu grafiklerde dağılımın ortanca, alt ve üst çeyrek sınırları da gösterilmiştir.

Zaman dizisi grafiklerinde (b) ile gösterilen normalleştirilmiş yağış indislerinin yıllararası değişim grafiklerinde (Şekil 3b, 4b, 5b), \pm 0.5 standardize değerlerin arasında kalan yağışlar normal kabul edilmiştir. Burada düz çizgi ile gösterilen 0 düzeyi, normalleştirilmiş dizinin uzun süreli ortalamasına karşılık gelir. +0.5 'in üzerindeki yağışlar genel olarak nemli, -0.5 'in altında kalan yağışlar genel olarak kurak koşullara karşılık gelir. Turgutlu meteoroloji istasyonunun 2007-2008 yağış ve sıcaklık verilerine ulaşılamadığı için, Turgutlu'nun zaman dizisi analizleri yapılamadı. 


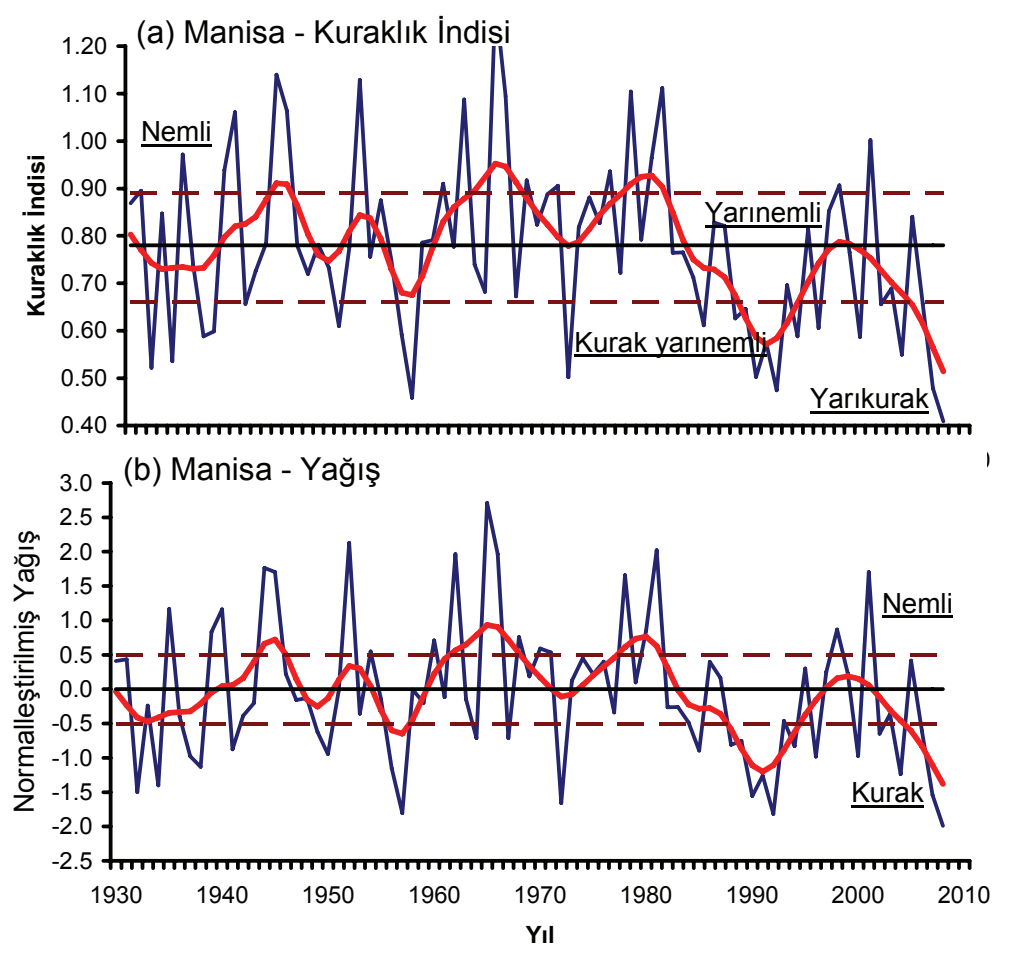

Şekil 3. Manisa'nın 9 noktalı Gauss süzgeci ile düzgünleştirilen uzun süreli (a) yıllık kuraklık indisi dizisindeki ve (b) normalleştirilmiş yıllık yağış anomalisi dizisindeki yıllararası değişimler. (a)'da, (-), 9 noktalı Gauss süzgecini; ( - ), kuraklık dizisinin ortancasını; (- - -), alt ve üst çeyrek değerlerini gösterir. (b)'de, $(-), 9$ noktalı Gauss süzgecini; ($-)$, normalleştirilmiş yağış dizisinin ortalamasını; (-- $),+0.5$ ve -0.5 standardize yağış düzeylerini gösterir.
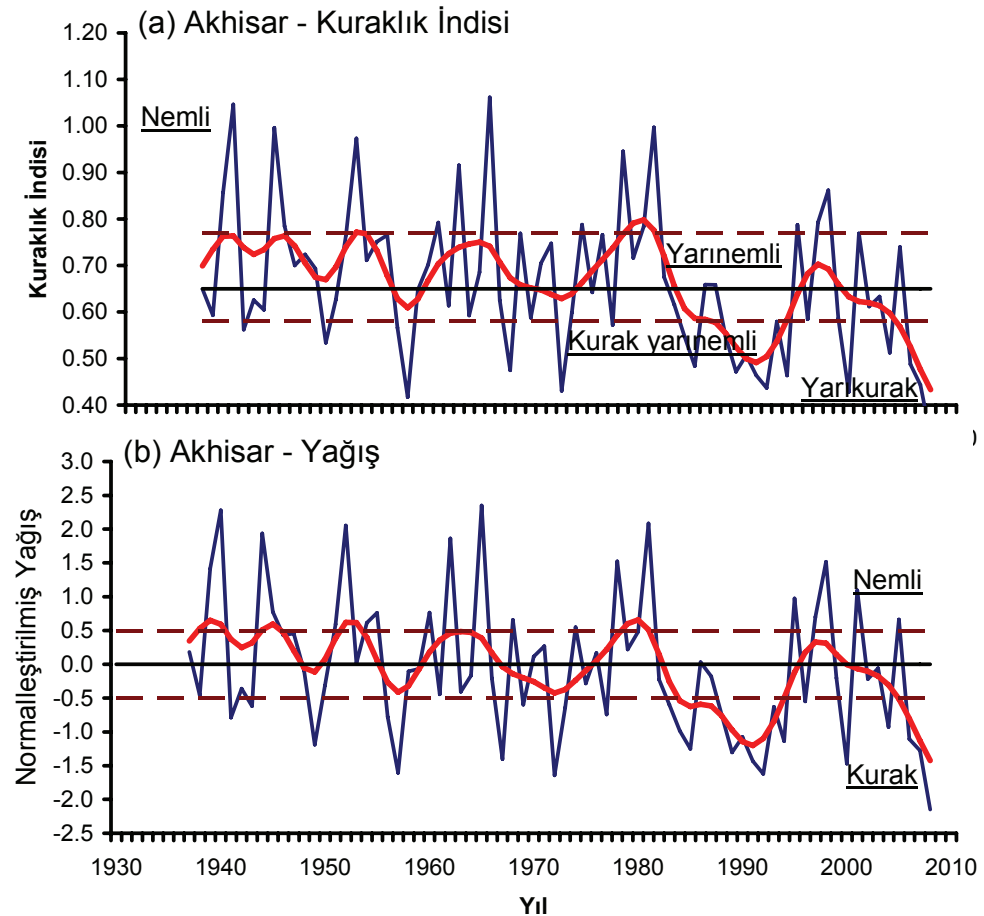

Şekil 4. Akhisar'ın uzun süreli (a) yıllık kuraklık indisi dizisindeki ve (b) normalleştirilmiş yıllık yağış anomalisi dizisindeki yıllararası değişimler. Grafik düzenlemeleri Şekil 3’teki gibidir. 


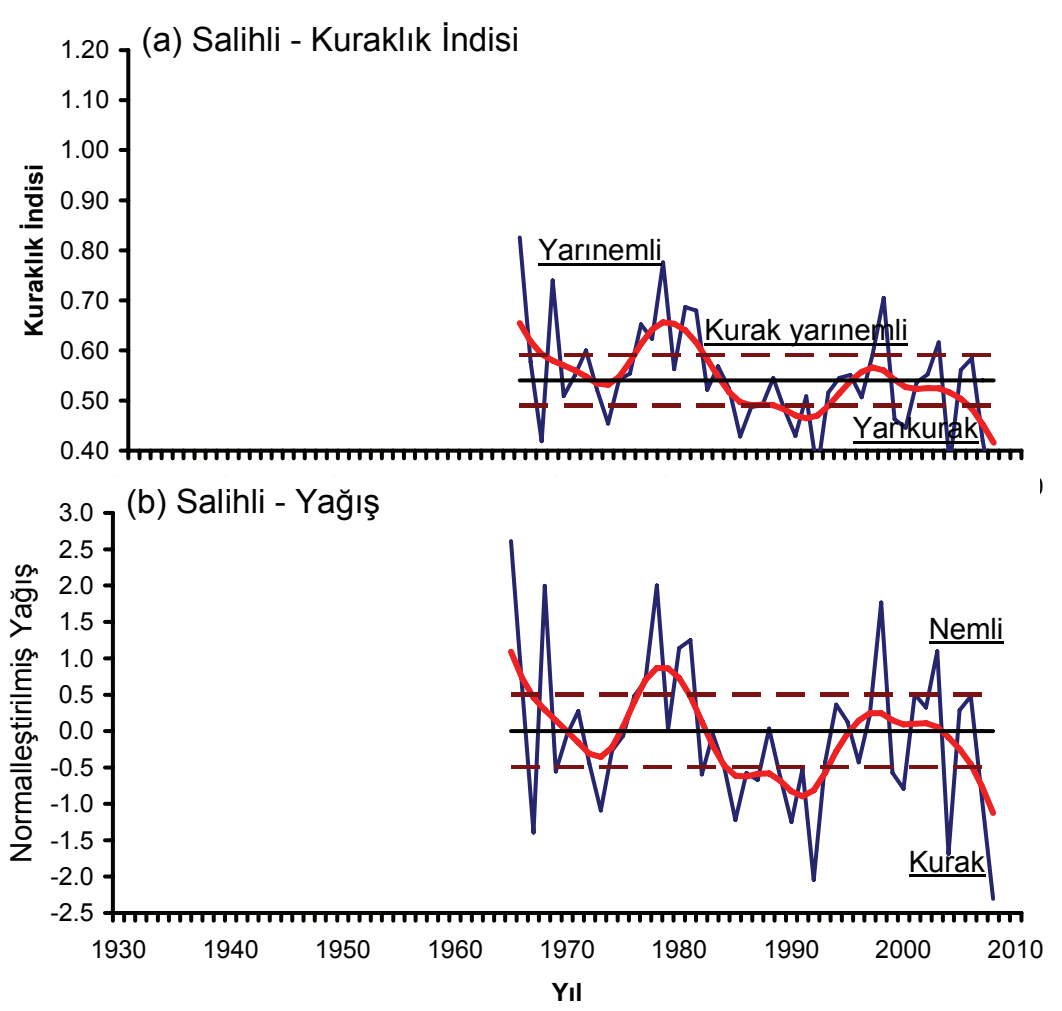

Şekil 5. Salihli’nin uzun süreli (a) yıllık kuraklık indisi dizisindeki ve (b) normalleştirilmiş yıllık yağış anomalisi dizisindeki yıllararası değişimler. Grafik düzenlemeleri Şekil 3'teki gibidir.

Çizelge 5. Manisa, Akhisar ve Salihli istasyonlarının normalleştirilmiş yağış indisi $(N Y \dot{I})$ ve kuraklık indisi $(K \dot{I})$ dizilerindeki uzun süreli eğilimleri belirlemek için uygulanan Mann-Kendall sıra ilişki katsayısı ( $\tau$ ) sınaması ve EKKDR katsayısı $\beta^{\prime}$ nın anlamlılı̆̆ için Student $t$ sınaması sonuçları. Mann-Kendall $\tau$ ve $\beta$ nın anlamlılığ için Student $t$ sınama örneklemdeğerlerinin anlamlılık düzeyleri parantez içindedir.

\begin{tabular}{lcccc}
\hline & \multicolumn{2}{c}{ Mann-Kendall $\tau$} & \multicolumn{2}{c}{ Student $t$} \\
\cline { 2 - 5 } Istasyon & $N Y \dot{I}$ & $K \dot{I}$ & NYI & $K \dot{I}$ \\
\hline Manisa & -0.11 & -0.14 & -1.40 & $-2.01^{*}$ \\
& $(0.17)$ & $(0.06)$ & $(0.17)$ & $(0.05)$ \\
Akhisar & $-0.20^{* *}$ & $-0.22^{* *}$ & $-2.67^{* *}$ & $-3.08^{* *}$ \\
& $(0.01)$ & $(0.005)$ & $(0.01)$ & $(0.003)$ \\
Salihli & -0.12 & $-0.21^{*}$ & -1.80 & $-2.73^{* *}$ \\
& $(0.24)$ & $(0.05)$ & $(0.08)$ & $(0.009)$ \\
\hline
\end{tabular}

(*) \% 5 anlamlılık düzeyindeki; (**) \% 1 anlamlılık düzeyindeki önemli eğilimleri gösterir.

Şekil 3, 4 ve 5'te verilen üç istasyonun normalleştirilmiş yıllık yağış indisi ve yıllık kuraklık indisi dizilerindeki yıllararası değişimler görsel olarak incelendiğinde, tüm dizilerde belirgin bir dalgalanma ile birlikte, özellikle 1980'lerin başından beri daha kurak koşullara doğru belirgin bir gidiş gözlenir. 1980'lerin sonundaki şiddetli kurak koşulların bir benzeri çok güncel bir kuraklık olayına karş1l1k gelen 2007-2008 döneminde (2006 sonundan 2008 sonuna kadar) yaşanmıştır.

Çizelge 5'te verilen eğilim sınamalarının sonuçlarına göre, Akhisar'ın yağış ve kuraklık indisi dizilerinde gözlenen azalma eğilimi, hem Mann-Kendall hem de EKKDR Student $t$ anlamlılık sınamalarına göre istatistiksel olarak 0.01 düzeyinde anlamlıdır. Manisa ve Salihli yıllık yağışlarında gözlenen azalma eğilimi, her iki yönteme göre de anlamlı değilken, Salihli kuraklık indisi dizisinde 
gözlenen azalma eğilimi Mann-Kendall yöntemine göre 0.05, EKKDR yaklaşımına göre 0.01 düzeyinde anlamlıdır. Manisa'da ise yalnız kuraklık indisi EKKDR'ye göre 0.05 düzeyinde anlamlıdır. Genel olarak dizilerdeki uzun dönemli dalgalanmaların uzun süreli eğilimleri bastırma ya da etkisini arttırma rolü vardır. Burada ise, son yıllarda yaşanan kuraklık olayının azalma eğilimini kuvvetlendirdiğini görmekteyiz.

Zaman dizisi grafiklerinden, özellikle kuraklık indisi yöntemine göre düzenlenenler, bu yöntem aynı zamanda bir çölleşmeye eğilimli (çölleşmenin etkilerine karşı açık olan) kurak iklimleri ve arazileri belirleme amacına yönelik olarak da yaygın olarak kullanıldığı için, yağışlarda gözlenen azalma eğiliminin sonucunda iklim koşulları açısından hangi koşullara ya da evreye (yarıkurak, kurakyarı-nemli, yarınemli ya da nemli, vb.) ulaşıldığı konusunda da bilgi elde edebiliriz. Buna göre, 1980'lere kadar yarınemli iklim koşullarının egemen olduğu Manisa'da, önce 1990'larda kurakyarınemli, sonra 2000'lerin sonuna doğru yarıkurak koşulların etkili olmaya başladığı gözlenmektedir (Şekil 3a). Benzer bir durum Akhisar'da da yaşanmaktadır (Şekil 4a). Salihli'de ise, 1980'lerde egemen olan yarınemli iklim koşullarından, önce kuru-yarınemli son yıllarda ise yarıkurak iklim koşullarına doğru belirgin bir geçiş yaşanmıştır (Şekil 5a).

\subsection{Akselendi Ovası'nda Çölleşme ve Kumul Oluşumu Üzerine}

\subsection{1. Çölleşmeye ilişkin temel kavramlar}

$\mathrm{Bu}$ noktada, iklimsel değişkenlik ve kuraklık açısından Akhisar'ın güneyinde yeralan Akselendi Ovası'ndaki çölleşme ve kumul oluşumu (Foto 1) ile iklim ve iklimsel değişimler arasındaki bağlantıların ele alınması ve genel bir bireşiminin yapılması da yararlı olacaktır. Bunun için, önce aşağıda kısaca arazi degradasyonu (yitirimi ya da bozulumu) ve çölleşme kavramları üzerinde duruldu (Türkeş, 1990, 1999, 2007, 2010b; UNCCD, 1995).

Arazi degradasyonu, kurak, yarlkurak ve kuru-yarınemli alanlarda doğal yağışlar ile beslenen tarım arazilerinin, çayır ve otlakların, korulukların ve ormanların, çeşitli arazi kullanımlarından ya da insan etkinliklerinden ve yerleşme düzenlerinden kaynaklanan birçok sürecin bileşimi sonucunda biyolojik ya da ekonomik verimliliklerinin azalması ya da kaybı olarak tanımlanır (UNCCD, 1995). Bu süreçler, genel olarak açağıdakileri içerir:

(a) Rüzgarın ve/ya da suyun oluşturduğu toprak erozyonu (aşınımı);

(b) Toprağın, fiziksel, kimyasal, biyolojik ya da ekonomik özelliklerinin bozulması ve

(c) Doğal vejetasyonda ortaya çıkan uzun süreli kayıplar.

Türkeş (1990) tarafindan, ekonomik ve biyolojik olarak üretken bir arazinin daha az üretken olması sonucunda ortaya çıkan ekolojik bozulma süreci olarak tanımlanan çölleşme'nin ileri aşamalarında, fiziksel bozulmalar ya da yeni jeomorfolojik oluşumlar (örn. kumul alanları, çöller, vb.) ortaya çıkabilir (Türkeş, 2007, 2010b). Gerçekte, çölleşme, hem insanın hoyrat arazi kullanımından hem de uzun süreli kuraklıklar gibi olumsuz iklim koşullarından kaynaklanır. Bazı çalışmalarda, çölleşmenin birçok etmenin karmaşık etkileşimlerinin bir sonucu olduğu ve doğrudan nedenlerin, nüfus yoğunluğunun, geleneklerin, arazi ayrıcalıklarının ve başka sosyoekonomik ve politik etmenlerin bir işlevi olan insan etkinlikleri ile bağlantılı olduğu öne sürülmüştür. Öte yandan, iklim ve toprak çeşitleri, çölleşmenin hızını ve şiddetini belirlemede önemli olmasına karşın, çoğu zaman bu etmenler, toprağın gelişimini ve taşınmasını yönlendiren egemen iklim açısından arazi kullanımı yönetimi ilkelerinin belirlenmesi ve uygulanmasında dikkate alınmamaktadır. 


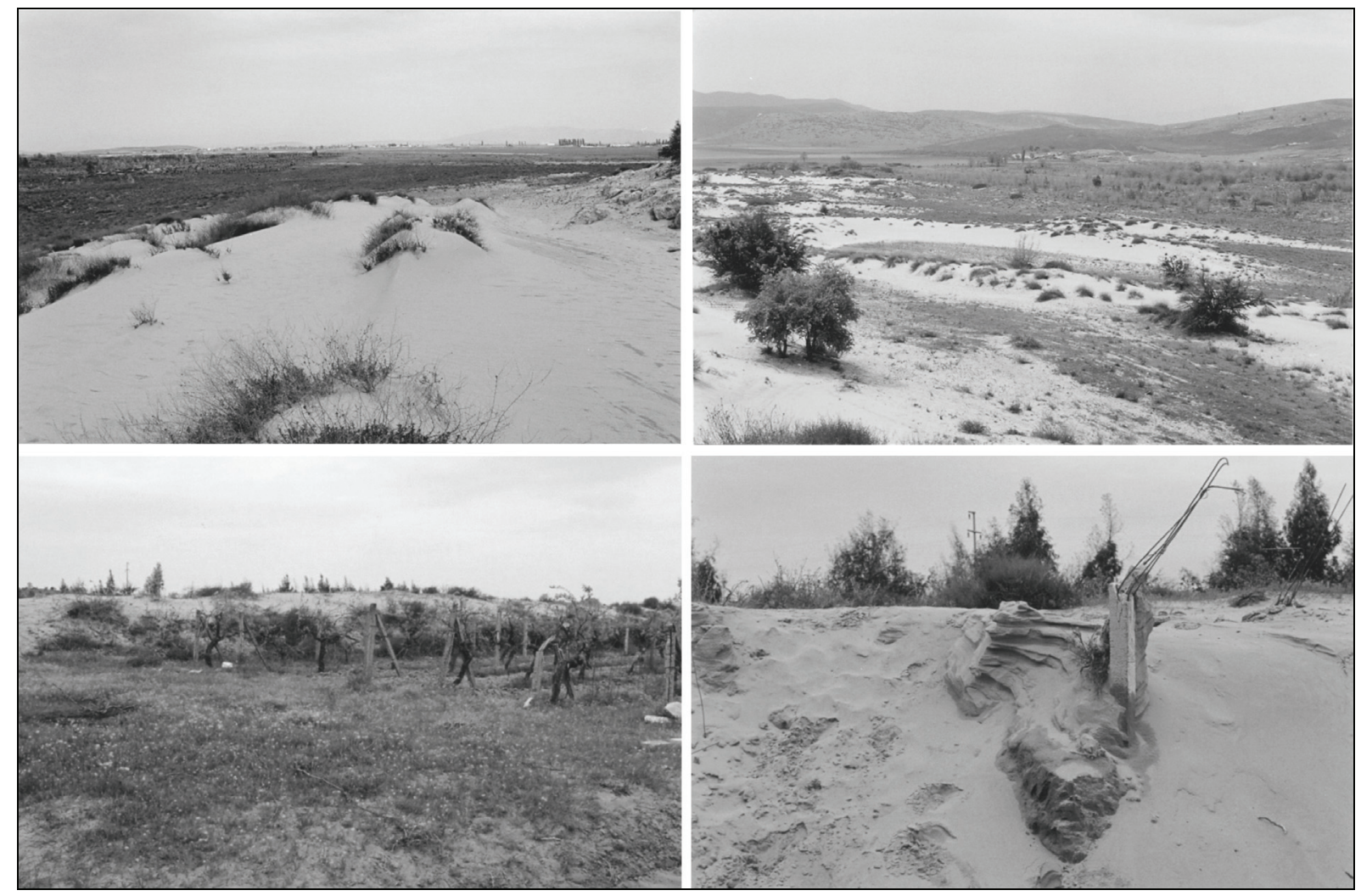

Foto 1. Akhisar Akselendi Ovası'nda kumul oluşumu ve çölleşme. Kumulların kurak yaz aylarında kuvvetlenen kuzeyli rüzgarların etkisiyle Kumçayı'nın eski yatağının güneyine doğru ilerlemesi sonucunda, yörenin ekonomik açıdan en değerli tarımsal ürünlerinden biri olan çekirdeksiz üzüm bağlarını, alansal olarak değișmekle birlikte yaklașık 3-4 m kalınlığındaki kum kütleleriyle kaplamış oluşuna dikkat ediniz (Foto: Murat Türkeş, 13 Nisan 2002).

Çölleşme, Çölleşme ile Savaşım Sözleşmesi’ndeyse, "iklimsel değişimleri ve insan etkinliklerini de içeren, fiziksel, biyolojik, siyasal, sosyal, kültürel ve ekonomik etmenler arasındaki karmaşık etkileşimlerin, kurak, yarlkurak ve kuru-yarınemli alanlarda oluşturduğu arazi degradasyonu" olarak tanımlanmıştır (UNCCD, 1995). Buna göre, kutup ve kutupaltı coğrafi kuşakları dışında dünyanın hemen her bölgesinde oluşabilen arazi yitirimi, kurak, yarıkurak ve kuruyarınemli arazilerde oluştuğunda çölleşme olarak kabul edilmiştir. Çölleşme, düşük toplam yağışa, yetersiz su kaynaklarına, uzun kurak mevsimlere, yinelenen kuraklık olaylarına, gevşek yüzey malzemesine ve ince toprak katmanına sahip, seyrek ve aynı zamanda hassas bir vejetasyon ile kaplanmış ortamlarda, hem daha sık oluşur hem de daha fazla etkili olur. Uzun süreli ve şiddetli kuraklık olayları gibi iklimle ilişkili etmenler, arazinin çölleşmeden etkilenebilirliğinde ve çölleşme süreçlerinin hızlanmasında bir artışa yol açabilir. Gerçekte, kuraklık ve yanlış arazi yönetimi, arazi ve su kullanımı ile toprak ve egemen iklim arasındaki uyumsuzluğun birleşiminin bir sonucudur.

\subsubsection{Akselendi Ovası'nda çölleşme ve kumul oluşumu}

Akhisar ilçesi güneyinde bulunan Akselendi Ovası, Akhisar havzası ovaları (Akhisar Mecidiye - Selçikli - Büknüş ve Akselendi) adıyla anılan ovalar grubu içinde yer alır. Ova, yaklaşık $70 \mathrm{~km}^{2}$ 'lik alanı ile bu ovaların en büyüğ̈̈dür. Akselendi Ovası'ndaki kumul oluşumunun nedenleri ve çevresel sonuçları, Öner ve Mutluer (1993) tarafindan, özellikle fiziki coğrafya etmen ve süreçleri dikkate alınarak ayrıntılı olarak incelenmiştir. Öner ve Mutluer (1993)'in değerlendirmelerine göre, Akselendi Ovası'nın doğusundaki yüksek alanlardan kaynağını alan, ovaya kadar Gördes çayı, ovaya girişinden sonraysa Kumçayı adını alan akarsu, doğu-batı yönünde bu ovayı geçtikten sonra, batıgüneybatıdan Kumçayı boğazını aşararak Gediz ırmağına bağlanıyormuş. 1950 li yıllara kadar 
Kumçayı, Akselendi ovasında çok yağışlı yıllarda şiddetli ve görece geniş alanlı taşkınlara neden olarak, oluşturduğu taşkın ovası üzerinde sürekli yatak değiştiriyordu. Ayrıca, özellikle yaz aylarındaki kurak dönemlerde, akarsuyun taşımış olduğu ince taneli alüvyonlar, genellikle kuzey sektörlü ve kuvvetli esen rüzgârlar tarafından geniş akarsu yatağından kaldırılarak güneye doğru süpürülüp taşınıyordu. Taşkınlar ve rüzgarın deflasyon etkisi, özellikle akarsu yatağının güneyinde kalan tarım arazilerini önemli ölçüde etkiliyordu. Akarsu taşkınları, akarsu kenarındaki tarım alanlarını tahrip ederken, kumların rüzgarlarla taşkın yatağından sökülüp güneye doğru süpürülmeleri sonucunda da ekili alanlar kumullar altında kalıyordu. Yine Öner ve Mutluer'e (1993) göre, 1950 lerin başlarında, Kumçayının yatağı Çömlekçi köyü yakınında güneye doğru çevrilerek bir derivasyon kanalı ile Gölmarmara'ya bağlanmıştır. Bu yatak değişikliği hem Kumçayı'nın ovadaki taşkınlarını önlemek, hem de Gediz ovalarındaki tarım alanlarının daha fazla sulanması amacıyla yapılmıştır. Başlangıçta taşkınların önlenmesi ve sulama açısından olumlu gibi görünen bu düzenleme, Kumçayının Akselendi ovasındaki yatağı yıl içinde artık daha uzun bir süre kuru kaldığı ve bu da rüzgarın deflasyon etkisini arttırdığı için, sonraki yıllarda giderek Akselendi ovasındaki kumulların daha hızlı yayılmasına yol açmıștır.

1970'li yıllarla birlikte, özellikle üzüm bağlarının ve meyve bahçelerinin artmasınının da katkısıyla, tarım alanlarının sulama gereksinimin artması ve genel olarak Ege ve Akdeniz bölgelerindeki şiddetli kuraklık olaylarının sıklığının artması ve kuvvetlenen kuraklaşma eğiliminin (Türkeş, 1996, 1998, 1999; Türkeş ve Tatl1, 2010; Türkeş vd., 2009, vb.) sonucunda, eski akarsu yatağına hiç su verilememiş ve buradaki geniş yatak bütün yıl boyu kuru kalmıştır. Bunun sonucunda, önceden kumullardan fazla etkilenmemiş olan tarım arazileri, giderek artan bir şekilde kumul tehdidi ile karşı karşıya kalmıştır. 1990 yıllarda Akselendi ovasındaki kumulların uzanışı kabaca kuzeybatıgüneydoğu doğrultusundaydı. Kumulların kum kaynağı durumundaki Kumçayı'nın eski yatağı dışında, asıl kumul alanı bu yataktan güneye doğru sivri ucu Kum tepe güneyinde kalan bir üçgeni andıracak şekilde uzanıyordu. Bu sınırlar içinde yaklaşı $6 \mathrm{~km}^{2}$, lik bir alan kaplamakta olan kumul alanında, kum örtüsünün kalınlığ 12000 'li yılların başında yaklaşık 3-4 metreye ulaşabilmekteydi (Foto 1). Ayrıca, kumul hareketleriyle örtülen arazilere ek olarak, rüzgarın taşıdı̆̆ 1 asılı çökellerin verimli tarım arazilerinin üzerinde birikmesi sonucunda, buradaki toprak özellikleri değişmiş ve arazi rüzgar aşınımına karşı daha duyarlı olmuştur.

Yeni bir çalışmada (Taysun vd., 2010), Akselendi Ovası'ndaki rüzgar erozyonunun etkileri, çökel taşınımı, alınan önlemlerin sonuçları ve geleceğe yönelik çözüm önerileri ele alınmıştır. Çalışmada, çeşitli toprak ve çökel çözümlemeleri ve istatistiksel yötemler kullanan Taysun vd. (2010), çalışma alanının rüzgarla taşınabilirlik grupları (WEG) haritasını oluşturmuştur. Yazarlar ayrıca, bir jeoistatistik program yardımıyla çalışma alanının potansiyel rüzgar aşınımıyla toprak kaybı haritasını hazırlamıştır. Taysun vd.'ye (2010) göre de, yıllık ortalama $600 \mathrm{~mm}$ dolayında yağış alan Akselendi Ovası'nda, rüzgar aşınımı çok etkilidir ve Kum Çayı yatağından kalkan kumlar ve oluşan kumullar Kum Çayı yatağının güneyindeki arazileri kaplamaktadır. Etkilenen arazilerin bir bölümünde, 0.84 mm'den daha büyük çaplı (daha iri) kum tanelerinin tutarı azalmış ve bunun sonucunda toprağın rüzgarla aşınması artmıştır.

Öner ve Mutluer (1993) çalışmalarında, kumul oluşumuna yol açan etmenleri fiziki ve beşeri olarak iki başlıkta toplayarak, bunlara ilişkin coğrafi değerlendirmelerini ayrıntılı olarak yapmıştır. Yazarlara göre, kumulların oluşmasında büyük ölçüde fiziki ve beşeri etmenler birlikte etkili olmasına karşın, beşeri etmenler genellikle fiziki etmenlerin olumsuz yönde gelişmesine neden olarak kumul oluşumunu hızlandırmıştır. Öner ve Mutluer (1993) ve Taysun vd. (2010), kumulların oluşumunu, rüzgar aşınımını, kumulların ve kumullarla kaplanan arazilerin jeomorfolojik ve toprak özelliklerini ve kumulların çevre üzerindeki etkilerini coğrafya ve toprak bilimi açısından ayrıntılı olarak ele aldıkları için, bu çalışmada bunlar üzerinde daha fazla durulmayacaktır. 

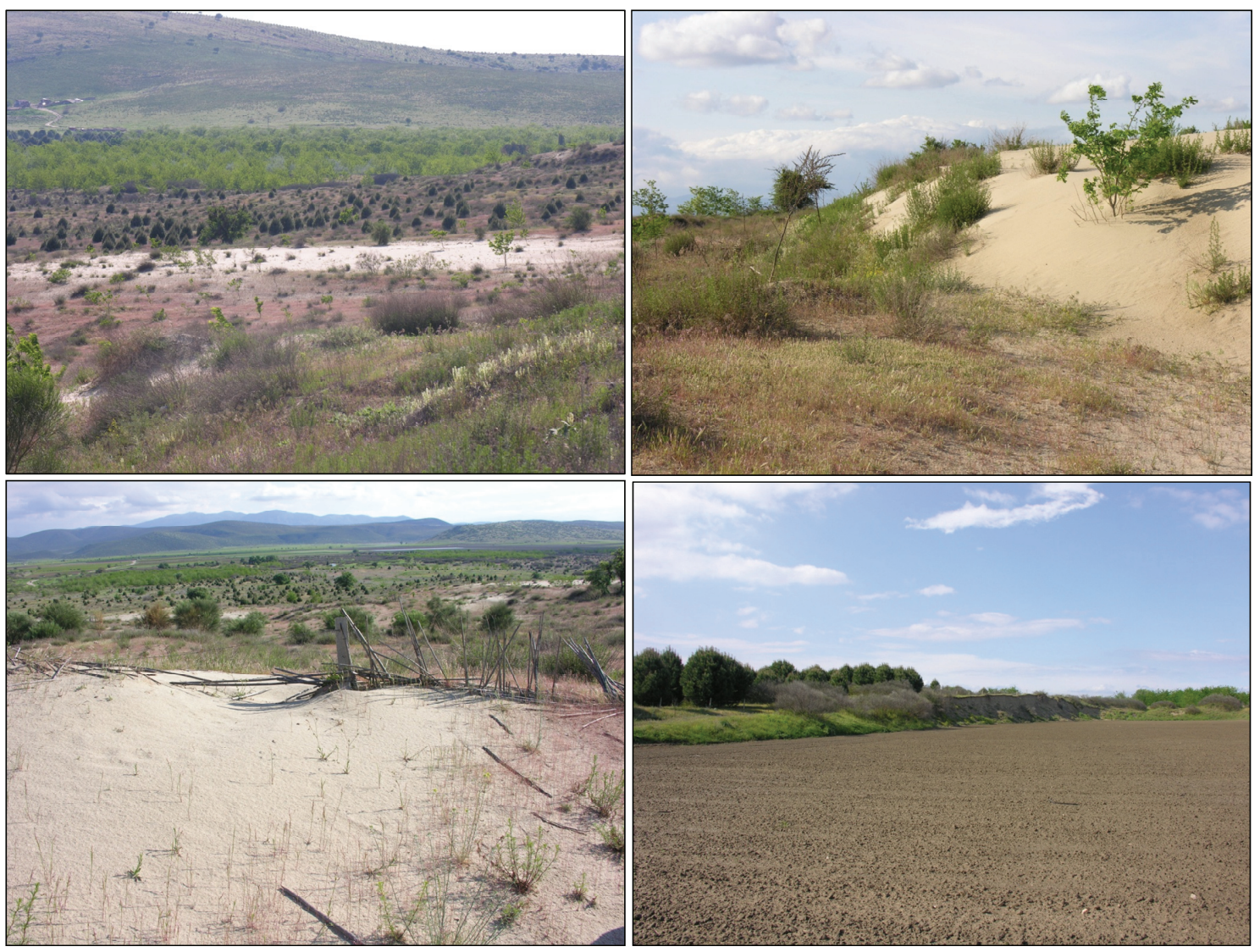

Foto 2. Akhisar Akselendi Ovası'ndaki çölleşme alanının Mart 2010'daki durumu ile kum taşınmasıı ve kumul ilerlemesine karşı yapılan ağaçlandırma/bitkilendirme çalışmaları ve sonuçları (Foto: Osman Derviş, 26 Nisan 2010).

Öte yandan, konuya bu çalışmanın sonuçları açısından bakıldığında, Akselendi Ovası'ndaki kumul oluşumu ve ortaya çıkan fiziki ve sosyoekonomik sonuçları, yaz kuraklıklarının da etkili olduğu kuru-yarınemli ve yarınemli bir alandaki arazi bozulumu ve iklim değişikliği [yağışlardaki, özellikle kışın gözlenen azalma eğilimleri (kuraklaşma) ve hava sıcaklıklarındaki, özellikle ilkbahar ve yaz mevsimlerinde minimum sıcaklıklarda gözlenen artış eğilimleri (1sınma)] sonucunda oluşan çölleşme süreçlerine ve fiziksel çölleşmeye çok çarpıcı ve öğretici bir örnektir. Akselendi Ovası'ndaki kumul oluşumu ve hareketlerinin 1950'li y1llara ve daha öncesine uzanan bir geçmişi ve çok çeşitli etmen, öğe ve süreçlere bağlanabilen nedenleri olmakla birlikte, bunun -büyük bir olasıllkla geçmişte olduğu gibi- genel olarak Ege Bölgesi'nde ve çalışma alanında 1970'li yıllarla birlikte özellikle Akdeniz yağış rejimi için çok önemli bir hidroklimatolojik önemi olan kış yağışlarında başlayan azalma eğilimi (kuraklaşma) ve genel olarak daha sık ve etkili olan kuraklık olayları (örn. 1972, 1980'ler ve 1990'ların başı, özellikle 1989-1990'daki kuraklık olayları) ile çok yakından bağlantılı olduğunu da söylemek gerekir.

Kumul alanında 1990'lı yılların öncesinde de kum taşınmasını ve kumul hareketlerini önlemek için hem çiftçilerin yerleştirdiği basit rüzgar-kum önleme perdeleriyle hem de Orman Bakanlığı'nca ağaçlandırma ve bitkilendirme yoluyla kumullarla (çölleşme) savaşım için bazı önlemler ve etkinlikler gerçekleştirilmiştir (Foto 2). 1990'lı yıllarla birlikte gerçekleştirilmiş olan ağaçlandırma ve bitkilendirme etkinlikleri sonucunda, kum taşınmasında ve kumul hareketlerinde, bu yüzden de kumul (çölleşme) alanında görece bir azalma olduğu söylenebilir (Foto 2). Rüzgar aşınımına ve kumul oluşumuna açık alanlarda, Orman Bakanlığı (günümüzde, Çevre ve Orman Bakanlığı) Ağaçlandırma ve Erozyon Kontrolü Genel Müdürlügü’nce yapılan ağaçlandırma ve bitkilendirme çalışmaları görece 
başarılı olmuştur (Foto 2). Ancak tarım arazilerinde ve rüzgar aşınımına çok açık olan Kum Çayı yatağı ve çevresindeki arazilerden kum alınması, aşırı otlatma ve başka yanlış arazi kullanımı etkinlik ve uygulamalarıyla bağlantılı sorunlara ek olarak, yağışların azalması ve kuraklaşma (yer altı ve yerüstü su kaynaklarının azalması ve zayıflaması) gibi olumsuz doğal etmen ve süreçler, bu çalışmaların başarısını ve geleceğini etkilemektedir.

\section{Sonuç ve Tartışma}

Türkiye, sahip olduğu iklim ve özellikle de yağış klimatolojisi özellikleri yüzünden, su kaynakları açısından zengin bir ülke değildir. Bu yüzden, 1970'li yılların başında beri orta ve doğu Akdeniz havzasında ve Türkiye'de sürmekte olan kuraklaşma eğiliminin kuvvetlenebileceği olasıllı̆̆ da dikkate alınarak, gelecekte karşı karşıya kalınabilecek olan ciddi su sıkıntısının önüne geçmek için, yasalarla desteklenen gerçekçi su politikalarının oluşturulması ve ivedilikle hayata geçirilmesi gerekir.

$\mathrm{Bu}$ kapsamda, insan kaynaklı iklim değişikliğinin (kuvvetlenen sera etkisine bağlı küresel iklim değişikliğinin) Türkiye'deki en önemli sonuçları arasında, hava sıcaklıklarının artması, şiddetli ve geniş alanlı kuraklık olaylarının sıklıklarının artması ile orman yangınlarının şiddetinde, süresinde ve etki alanında ortaya çıkabilecek olan artışlar sıralanabilir. Orman yangınlarındaki artışların belirtileri, daha şimdiden subtropikal iklim kuşağının birçok bölgesinde, Akdeniz havzasına batı ve kuzeyden komşu ülkelerde ve Türkiye'de yaşanmaktadır. Büyük Akdeniz ikliminin doğal bir sonucu olarak, Karadeniz Bölgesi ve Kuzeydoğu Anadolu bölümü dışında, Türkiye'nin geniş bir alanında sıcak ve kurak bir yaz mevsimi egemendir. 1970'lerin başından beri yağışlarda gözlenen azalma eğilimleri de dikkate alındığında (örn. Türkeş, 1996, 1998, 1999; Türkeş ve Tatlı, 2010; Türkeş vd., 2009), Türkiye'de her zaman var olan orman yangını olasılığı ve riski (Türkeş, 2007), birçok bölgede çok sıcak ve kurak geçen 2007 ve 2008 yaz mevsimlerinde yaşandığı gibi, daha büyük bir sorun olarak karşımıza çıkabilecektir.

$\mathrm{Bu}$ çalışmada da, normalleştirilmiş yıllık yağış ve yıllık kuraklık indisi dizilerine uygulanan eğilim sınamaları, Manisa ve Akhisar yörelerinde belirgin bir kuraklaşma eğiliminin yaşandığını ve bu eğilimin 1980'lerle birlikte kuvvetlendiğini, 2007-2008 döneminde ise çok şiddetlendiğini göstermiştir. Çalışma alanında, genel olarak, yarınemli iklim koşullarından daha kurak ve sıcak kuruyarınemli ve/ya da yarıkurak iklim koşullarına doğru belirgin bir değiş̧im belirlenmiş̧tir. Bu önemli bir iklim değişikliği sinyalidir ve Akhisar, Manisa ve Gediz ovalarındaki arazi ve su kaynakları üzerinde var olan sürdürülebilir olmayan aşırı ve yanlış insan kullanımlarından kaynaklanan sorunları kuvvetlendirebilecek düzeyde ciddi bir ek baskı oluşturmaktadır.

Yörede günümüzde egemen olan tüm iklim çeşitlerinin ve yağış rejiminin ortak özellikleri, çalışmanın ilgili bölümlerinde açıklanan su bilançolarına dayalı toprak-su dengesinin durumu ve yıl içindeki değişiminin bilimsel bireşiminden de açıkça görüldüğü gibi, hem çok sıcak ve şiddetli kurak bir yaz mevsiminin hem de şiddetli bir yıllık toprak nem eksikliğinin (su açığının) var olmasıdır.

$\mathrm{Bu}$ sonuçlar, klimatolojik yaz kuraklığına, yetersiz yağış koşullarına ve denk kapanmayan (açık veren) toprak-nem bütçesine ek olarak, yörenin kış kuraklıklarına açık olma eğilimi de dikkate alındığında, doğal yağışlara dayalı su kaynaklarının yetersiz ve ancak hassas bir denge ile varlığını sürdürdüğünü gösterir. Yöredeki bugünkü iklim koşulları ve değişkenlik özellikleri açısından, ne tarımsal amaçlı geleneksel su kullanımlarına ve damlama ya da yağmurlama sulama gibi çağdaş verimli sulama teknikleri ile yapılan sulama etkinliklerine ne de içme suyuna tam anlamıyla yetecek kadar bol ve nitelikli bir su varlı̆̆ 1 söz konusu değildir.

$\mathrm{Bu}$ yüzden Manisa ve Akhisar yörelerinde, var olan su kullanımlarına ve yer altı/yerüstü su kaynakları üzerinde ek bir baskı yaratabilecek, onları daha fazla sömürmeye yol açabilecek herhangi bir insan etkinliği, özellikle yeraltı ve yerüstü su kaynaklarından çok büyük tutarlarda yararlanmayı planlayan her türlü madencilik etkinlikleri, yörenin kuru-yarınemli ve yarıkurak koşullarını daha kurak koşullara doğru şiddetlendirebilecektir. Bu ise, yörenin hassas bir denge üzerinde varlığını sürdürmeye çalışan tarım ve su kaynakları üzerinde onarılması olanaksız ya da onlarca yıl etkili olabilecek çok 
tehlikeli hasarlar yaratacak ve yörenin çölleşme süreçlerinden etkilenebilirliğini daha da kuvvetlendirebilecektir.

\section{Teşekkür}

Yerbulduru haritasını hazırlayan Çanakkale Onsekiz Mart Üniversitesi Coğrafya Bölümü araştırma görevlisi Muhammed Zeynel Öztürk'e; su bilançolarının hesaplanmasındaki yardımı için DMİ Araştırma Şubesi'nden Ziraat Mühendisi A. Serap Akgündüz'e ve klimatolojik/meteorolojik verilerin sağlanmasında her zaman yardımcı olan DMİ yönetici ve çalışanlarına çok teşekkür ederim.

\section{Referanslar}

Demir, İ.; Kılıç, G.; Coşkun, M. (2008) "Climate predictions for Turkey using PRECIS Regional Climate Model: Scenario HaDAMP3 SRES A2." In Proceedings of the International Fourth Symposium on Atmospheric Sciences, 25-28 March 2008, İstanbul, Turkey.

IPCC. (2000) Special Report on Emissions Scenarios - A Special Report of Working Group III of the Intergovernmental Panel on Climate Change (IPCC) (Nakićenović, et al., lead authors), Cambridge University Press, New York.

IPCC. (2007) Climate Change 2007: The Physical Science Basis. Contribution of Working Group I to the Fourth Assessment Report of the Intergovernmental Panel on Climate Change (ed. Solomon, S., D. Qin, M. Manning, Z. Chen, M. Marquis, K.B. Averyt, M.Tignor and H.L. Miller). Cambridge University Press, Cambridge, United Kingdom and New York, NY, USA.

Koçman, A. (1993) İnsan Faaliyetleri ve Çevre Üzerine Etkileri Açısından Ege Ovalarının İklimi. Ege Üniversitesi Edebiyat Fakültesi Yayınları No: 73, Ege Üniversitesi Basımevi, Bornova - İzmir.

Öner, E.; Mutluer, M. (1993) “Akselendi Ovasında kumul oluşumu ve buna bağlı çevre sorunları.” Ege Coğrafya Dergisi, 7 , $133-160$.

Önol, B.; Semazzi, F. H. M. (2009) "Regionalization of climate change simulations over the Eastern Mediterranean.” Journal of Climate, 22, 1944-1960.

Tatli, H.; Dalfes, H. N.; Menteş, Ş. S. (2004) "A statistical downscaling method for monthly total precipitation over Turkey." International Journal of Climatology, 24, 161-180

Tatli, H.; Dalfes, H. N.; Menteş, Ş. S. (2005) "Surface air temperature variability over Turkey and its connection to large scale upper air circulation via multivariate techniques." International Journal of Climatology, 25, 331-350.

Taysun, A.; Özden, N.; Taysun, K. Ş.; Okur, M.; Okur, O. (2010) "Manisa Akselendi Ovasında rüzgar erozyonunun etkileri, alınan önlemlerin durumu ve etkinliği ile geleceğe yönelik çözüm önerileri." İçinde Çölleşme İle Mücadele Sempozyumu Tebliğler Kitabı, T.C. Çevre ve Orman Bakanlı̆̆ı - Ağaçlandırma ve Erozyon Kontrolü Genel Müdürlüğü, 361-369.

Temuçin, E. (1991) Manisa - Akhisar Ovalarında İklim ve Ortam İlişkileri (Uygulamalı Bir Coğrafya Araştırması). Ege Üniversitesi Sosyal Bilimler Enstitüsü Doktora Tezi (yayımlanmamış), İzmir.

Thornthwaite, C. W. (1948) “An Approach toward a rational classification of climate.” Geography Review, 38, 55-94.

Trigo, R.; Xoplaki, E.; Zorita, E.; Luterbacher, J.; Krichak, S.; Alpert, P.; Jacobeit, J.; Saenz, J.; Fernandez, J.; GonzalezRouco, F.; Garcia-Herrera, R.; Rodo, X.; Brunetti, M.; Nanni, T.; Maugeri, M.; Türkeş, M.; Gimeno, L.; Ribera, P.; Brunet, M.; Trigo, I.; Crepon, M.; Mariotti, A. (2006) "Relations between variability in the Mediterranean region and mid-latitude variability." In Chapter 3 of Mediterranean Climate Variability (ed. Lionello, P., Malanotte-Rizzoli, P. and Boscolo, R.). pp. 179-226, Elsevier Developments in Earth \& Environmental Sciences 4, Amsterdam,

Türkeş, M. (1990) Türkiye'de Kurak Bölgeler ve Önemli Kurak Ylllar. İstanbul Üniversitesi Deniz Bilimleri ve Coğrafya Enstitüsü Doktora Tezi (yayımlanmamış), İstanbul.

Türkeş, M. (1996) "Spatial and temporal analysis of annual rainfall variations in Turkey." International Journal of Climatology, 16, 1057-1076.

Türkeş, M. (1998) "Influence of geopotential heights, cyclone frequency and Southern Oscillation on rainfall variations in Turkey." International Journal of Climatology, 18, 649-680.

Türkeş, M. (1999) "Vulnerability of Turkey to desertification with respect to precipitation and aridity conditions." Turkish Journal of Engineering and Environmental Sciences, 23, 363-380.

Türkeş, M. (2003a) "Küresel iklim değişikliği ve gelecekteki iklimimiz.” İçinde 23 Mart Dünya Meteoroloji Günü Kutlaması, Gelecekteki İklimimiz Paneli Bildiriler Kitabı (ed. Türkeş, M.), 12-37. Devlet Meteoroloji İşleri Genel Müdürlüğü, 23 Mart 2003, Ankara.

Türkeş, M. (2003b) "Spatial and temporal variations in precipitation and aridity index series of Turkey." In Mediterranean Climate - Variability and Trends, Regional Climate Studies (ed. Bolle, H. J.), pp. 181-213. Springer Verlag, Heidelberg.

Türkeş, M. (2007) “Türkiye'nin kuraklığa, çölleşmeye eğilimi ve iklim değişikliği açısından değerlendirilmesi.” Pankobirlik, 91, 38-47.

Türkeş, M. (2008a) “İklim değiş̧ikliği ve küresel 1sınma olgusu: Bilimsel değerlendirme. Küresel Isınma ve Kyoto Protokolü: İklim Değişikliğinin Bilimsel, Ekonomik ve Politik Analizi” (Yayına Hazırlayan, Karakaya, E.), 21-57. Bağlam Yayınları No. 308, Bağlam Yayıncılık, İstanbul. 
Türkeş, M. (2008b) "Küresel iklim değişikliği nedir? Temel kavramlar, nedenleri, gözlenen ve öngörülen değişiklikler." İklim Değişikliği ve Çevre, 1, 45-64.

Türkeş, M. (2008c) “Gözlenen iklim değişiklikleri ve kuraklık: Nedenleri ve geleceği." Toplum ve Hekim, 23, 97-107.

Türkeş, M. (2009a) Klimatolojik ve Hidrolojik Verilerin Türdeşlik Analizi. Çanakkale Onsekiz Mart Üniversitesi, FenEdebiyat Fakültesi Coğrafya Bölümü, Coğ525 Yüksek Lisans Ders Notları (yayımlanmamış), Çanakkale.

Türkeş, M. (2009b) Klimatolojik ve Hidrolojik Verilerin İklimsel Değişkenlik Analizi. Çanakkale Onsekiz Mart Üniversitesi, Fen-Edebiyat Fakültesi Coğrafya Bölümü, Coğ526 Yüksek Lisans Ders Notları (yayımlanmamış), Çanakkale.

Türkeş, M. (2010a) "Küresel İklim Değişikliğii: Başlıca Nedenleri, Gözlenen ve Öngörülen Değişiklikler ve Etkileri." Çağrılı Bildiri, İçinde Uluslararası Katılımlı 1. Meteoroloji Sempozyumu Bildiri Kitabı, Devlet Meteoroloji İşleri Genel Müdürlüğ̈̈, 9-38.

Türkeş, M. (2010b) “BM Çölleşme İle Savaşım Sözleşmesi'nin İklim, İklim Değişikliği ve kuraklık açısından çözümlenmesi ve Türkiye'deki uygulamalar (Analysis of the UN Convention to Combat Desertification with respect to the Climate, Climate Change and Drought, and Applications in Turkey)." İçinde Çölleşme İle Mücadele Sempozyumu Tebliğler $K i t a b l$, T.C. Çevre ve Orman Bakanlığı - Ağaçlandırma ve Erozyon Kontrolü Genel Müdürlüğü, 601-616.

Türkeş, M.; Acar, Z. (2008) "Biga Yarımadası hava sıcaklıklarındaki eğilimler-değişiklikler ve atmosferik uzakbağlantı desenleri ile ilişkileri.” İçinde IV. Atmosfer Bilimleri Sempozyumu Bildiri Kitabı, 481-491. İ.T.Ü. Uçak ve Uzay Bilimleri Fakültesi, 25-28 Mart 2008, İstanbul.

Türkeş, M.; Erlat, E. (2003) "Precipitation changes and variability in Turkey linked to the North Atlantic Oscillation during the period 1930-2000.” International Journal of Climatology, 23, 1771-1796.

Türkeş, M.; Erlat, E. (2005) "Climatological responses of winter precipitation in Turkey to variability of the North Atlantic oscillation during the period 1930-2001." Theoretical and Applied Climatology, 81, 45-69.

Türkeş, M.; Tatlı, H. (2008) "Aşırı kurak ve nemli koşulların belirlenmesi için yeni bir standartlaştırılmış yağış indisi (yeniSPI): Türkiye’ye uygulanması." İçinde IV. Atmosfer Bilimleri Sempozyumu Bildiri Kitabı, İ.T.Ü. Uçak ve Uzay Bilimleri Fakültesi, 528-538.

Türkeş, M.; Tatlı, H. (2009) "Use of the standardized precipitation index (SPI) and modified SPI for shaping the drought probabilities over Turkey.” International Journal of Climatology, 29, 2270-2282.

Türkeş, M.; Tatl1, H. (2010) "Kuraklık ve yağış etkinliği indislerinin çölleşmenin belirlenmesi, nitelenmesi ve izlenmesindeki rolü (The Role of Drought and Precipitation Severity Indices for Determination, Characterization and Monitoring of the Desertification)." İçinde Çölleşme İle Mücadele Sempozyumu Tebliğler Kitabı, T.C. Çevre ve Orman Bakanlı̆̆g Ağaçlandırma ve Erozyon Kontrolü Genel Müdürlüğü, 245-263.

Türkeş, M.; Sümer, U. M. (2004) "Spatial and temporal patterns of trends and variability in diurnal temperature ranges of Turkey." Theoretical and Applied Climatology, 77, 195-227.

Türkeş, M.; Sümer, U. M.; Demir, İ. (2002) "Re-evaluation of trends and changes in mean, maximum and minimum temperatures of Turkey for the period 1929-1999." International Journal of Climatology, 22, 947-977.

Türkeş, M.; Koç, T.; Sarış, F. (2009) "Spatiotemporal variability of precipitation total series over Turkey." International Journal of Climatology, 29, 1056-1074.

UNCCD. (1995) The United Nations Convention to Combat Desertification in those Countries Experiencing Serious Drought and/or Desertification, Particularly in Africa, Text with Annexes, United Nations Environment Programme (UNEP), Geneva.

WMO. (1966) Climatic Change. World Meteorological Organization (WMO), Technical Note No. 79, Geneva.

Wonnacott, T. H.; Wonnacott, R. J. (1972) Introductory Statistics. John Wiley and Sons Inc. 